Article

\title{
Synthesis and Structure of Iron (II) Complexes of Functionalized 1,5-Diaza-3,7-Diphosphacyclooctanes
}

\author{
Yulia S. Spiridonova, Yulia A. Nikolaeva, Anna S. Balueva*, Elvira I. Musina ${ }^{\mathbb{D}}$, Igor A. Litvinov ${ }^{\mathbb{D}}$, \\ Igor D. Strelnik, Vera V. Khrizanforova, Yulia G. Budnikova $\mathbb{D}$ and Andrey A. Karasik
}

Arbuzov Institute of Organic and Physical Chemistry, FRC Kazan Scientific Center, Russian Academy of Sciences, Arbuzov str. 8, 420088 Kazan, Russia; aik79@iopc.ru (Y.S.S.); nikolaeva@iopc.ru (Y.A.N.); elli@iopc.ru (E.I.M.); litvinov@iopc.ru (I.A.L.); igorstrelnik@iopc.ru (I.D.S.);

KhrizanforovaVera@yandex.ru (V.V.K.); yulia@iopc.ru (Y.G.B.); karasik@iopc.ru (A.A.K.)

* Correspondence: balueva62@mai.ru; Tel.: +78-43-272-7392

Academic Editor: György Keglevich

Received: 24 July 2020; Accepted: 17 August 2020; Published: 19 August 2020

\begin{abstract}
In order to synthesize new iron (II) complexes of 1,5-diaza-3,7-diphosphacyclooctanes with a wider variety of the substituents on ligands heteroatoms (including functionalized ones, namely, pyridyl groups) and co-ligands, it was found that these ligands with relatively small phenyl, benzyl, and pyridin-2-yl substituents on phosphorus atoms in acetonitrile formed bis-P,P-chelate cis-complexes $\left[\mathrm{L}_{2} \mathrm{Fe}\left(\mathrm{CH}_{3} \mathrm{CN}\right)_{2}\right]^{2+}\left(\mathrm{BF}_{4}\right)_{2}{ }^{-}$, whereas P-mesityl-substituted ligand formed only monoligand P,P-complex $\left[\mathrm{LFe}\left(\mathrm{CH}_{3} \mathrm{CN}\right)_{4}\right]^{2+}\left(\mathrm{BF}_{4}\right)_{2}{ }^{-}$. 3,7-dibenzyl-1,5-di(1'-(R)- phenylethyl)-1,5-diaza-3,7-diphosphacyclooctane reacted with hexahydrate of iron (II) tetrafluoroborate in acetone to give an unusual bis-ligand cationic complex of the composition $\left[\mathrm{L}_{2} \mathrm{Fe}\left(\mathrm{BF}_{4}\right)\right]^{+} \mathrm{BF}_{4}{ }^{-}$, where two fluorine atoms of the tetrafluoroborate unit occupied two pseudo-equatorial positions at roughly octahedral iron ion, according to X-ray diffraction data. 1,5-diaza-3,7-diphosphacyclooctanes replaced tetrahydrofurane and one of the carbonyl ligands of cyclopentadienyldicarbonyl(tetrahydrofuran)iron (II) tetrafluoroborate to form heteroligand complexes $[\mathrm{CpFeL}(\mathrm{CO})]^{+} \mathrm{BF}_{4}{ }^{-}$. The structural studies in the solid phase and in solutions showed that diazadiphosphacyclooctane ligands of all complexes adopted chair-boat conformations so that their nitrogen atoms were in close proximity to the central iron ion. The redox properties of the obtained complexes were performed by the cyclic voltammetry method.
\end{abstract}

Keywords: 1,5-diaza-3,7-diphosphacyclooctane; iron; complex; synthesis; structure; redox properties

\section{Introduction}

The complexes of aminomethylphosphines with earth-abundant metals, such as nickel, cobalt, and iron, draw permanent attention as molecular catalysts and electrocatalysts for the activation of small molecules $\left(\mathrm{H}_{2}, \mathrm{~N}_{2}, \mathrm{CO}_{2}\right.$, etc.) [1-6]. The metal complexes of cyclic and acyclic aminomethylphosphines-containing amine centers in the main framework of a diphosphine ligand as proton relay act as the mimetics of the [FeFe]- and [NiFe]-hydrogenases, which are fast and efficient catalysts for the oxidation/generation of $\mathrm{H}_{2}$ [1-4]. The most studied objects are the nickel (II) complexes of 1,5-diaza-3,7-diphosphacyclooctanes, which show the high effectiveness in the electrocatalysis, both of the reduction of protons to generate $\mathrm{H}_{2}$ and of the oxidation of $\mathrm{H}_{2}[1-3,7]$, and have been successfully used as both the cathode and anode catalysts in fuel cells $[4,8,9]$. A very wide variation of the substituents on the ligands heteroatoms has been performed for these nickel-containing complexes in order to find the most effective and convenient catalysts for different applications $[2,7,8,10-13]$.

It has been shown that the nature of the central ion could essentially influence on the type of the complexes formed on the basis of 1,5-diaza-3,7-diphosphacyclooctanes. In particular, the interaction of these ligands with chromium dichloride leads to the unexpected ring expansion 
and the formation of the chromium (II) complexes of 12-membered $\mathrm{P}_{3} \mathrm{~N}_{3}$ and 16-membered $\mathrm{P}_{4} \mathrm{~N}_{4}$ macrocyclic aminomethylphosphines [14]. Another example of the ring expansion of 1,5-di- $p$-tolyl-3,7di(pyridine-2'-yl)-1,5-diaza-3,7-diphosphacyclooctane on $\mathrm{Au}_{3}$ cluster into 16-membered $\mathrm{P}_{4} \mathrm{~N}_{4}$ macrocycle has been observed [15]; it should be mentioned that this ligand transformation does not take place, both for other diazadiphosphacyclooctane ligands [15] and for other gold cores [16,17]. These data indicate that the formation of the metal complexes of diazadiphosphacyclooctanes cannot be considered a completely predictable process.

The iron complexes of 1,5-diaza-3,7-diphosphacyclooctanes are less studied in spite of their promising activity in $\mathrm{H}_{2}$ splitting and electrooxidation [3,18-20] and $\mathrm{N}_{2}$ binding and activation [5]. In particular, the set of substituents on phosphorus atoms of the investigated $\mathrm{P}_{2} \mathrm{~N}_{2}$ ligands is restricted and includes phenyl [21-24], tert-butyl [19,20,24,25], cyclohexyl [21,24], and benzyl groups [24], whereas the nitrogen atoms bear phenyl or benzyl groups. These diphosphines are used for the synthesis of bis-ligand iron (II) complexes [21,23] or more often for the preparation of heteroligand complexes containing cyclopentadienyl $[19,20,22,25]$ or benzenedithiolate ligands [24]. The cyclopentadienyl-containing complexes draw the main interest due to their activity in hydrogen electrooxidation $[3,19,20,25]$. The only additionally functionalized diazadiphosphacyclooctane ligand, namely, 1,5-diphenyl-3,7-bis(2'-diphenylphosphinoethyl)-1,5-diaza-3,7-diphosphacyclooctane, has been used for the synthesis of unusual square planar iron complexes stabilized by the coordination with exocyclic phosphino groups, which are able to activate both hydrogen and nitrogen molecules [5,18].

It should be mentioned that the varying of the substituents on the nitrogen atoms of acyclic $\mathrm{P}_{2} \mathrm{~N}$ ligands, namely, bis(diethylphosphinomethyl)organylamines, has shown the essential influence of the nature of these substituents on the activity of the corresponding iron (II) complexes in the hydrogen electrooxidation [26]. These data indicate that the wider variety of the diazadiphosphacyclooctane ligands of iron complexes and the further study of their structures and properties is expedient for the search of new catalysts on the basis of these compounds.

The synthesis of various types of homo- and heteroligand new iron (II) complexes of 1,5-diaza-3,7-diphosphacyclooctanes, including additionally functionalized P-pyridyl substituted ligands, and the results of our study of their structures and redox properties were reported in this contribution.

\section{Results}

1,5-Diaza-3,7-diphosphacyclooctanes 1-4 with relatively small substituents on phosphorus atoms, namely, phenyl, benzyl, and pyridin-2-yl groups, reacted with hexa(acetonitrile)iron (II) tetrafluoroborate in acetonitrile to give yellow or orange bis-ligand complexes $\left[\mathrm{L}_{2} \mathrm{Fe}\left(\mathrm{CH}_{3} \mathrm{CN}\right)_{2}\right]^{2+}$ $\left(\mathrm{BF}_{4}\right)_{2}{ }^{-} 6-9$, according to the data of elemental analysis. In ESI or MALDI mass-spectra of all these complexes, the peaks of ions containing two diazadiphosphacyclooctane moieties, iron ion, and in some cases, various co-ligands were observed. ${ }^{31} \mathrm{P}-\mathrm{NMR}$ spectra of complexes $\mathbf{6 - 9}$ showed two complex second-order multiplets of the equal intensity in the ranges 25.6-34.7 and 34.2-41.2 ppm. This spectral pattern is typical for $\mathrm{AA}^{\prime} \mathrm{BB}^{\prime}$ spin system of cis-iron (II) complexes with the strongly distorted octahedral configuration of the central ion-containing two P,P-chelating diphosphine ligands and two acetonitrile co-ligands, which occupy formally equatorial positions [21], so it indicated the analogous cis-structures of the complexes 6-9 (Scheme 1). Their ${ }^{1} \mathrm{H}-\mathrm{NMR}$ spectra also indicated the highly asymmetric structures of the complexes. The substituents on phosphorus atoms were mutually nonequivalent; the substituents on nitrogen atoms provided two sets of the corresponding signals, which probably corresponded to the chair-boat conformation of the cyclic diphosphine ligands so that two halves of the ligand molecule were in the different spatial environment (Figure 1). One of the nitrogen atom (and the corresponding substituent) of each ligand was in close proximity to the second diazadiphosphacyclooctane ligand, whereas the other nitrogen atom and its substituent were located 
on the side of acetonitrile ligand and took the remote positions. The very complex spectral patterns observed for the protons of $\mathrm{P}_{-} \mathrm{CH}_{2}-\mathrm{N}$ fragments were in accordance with these conformations.

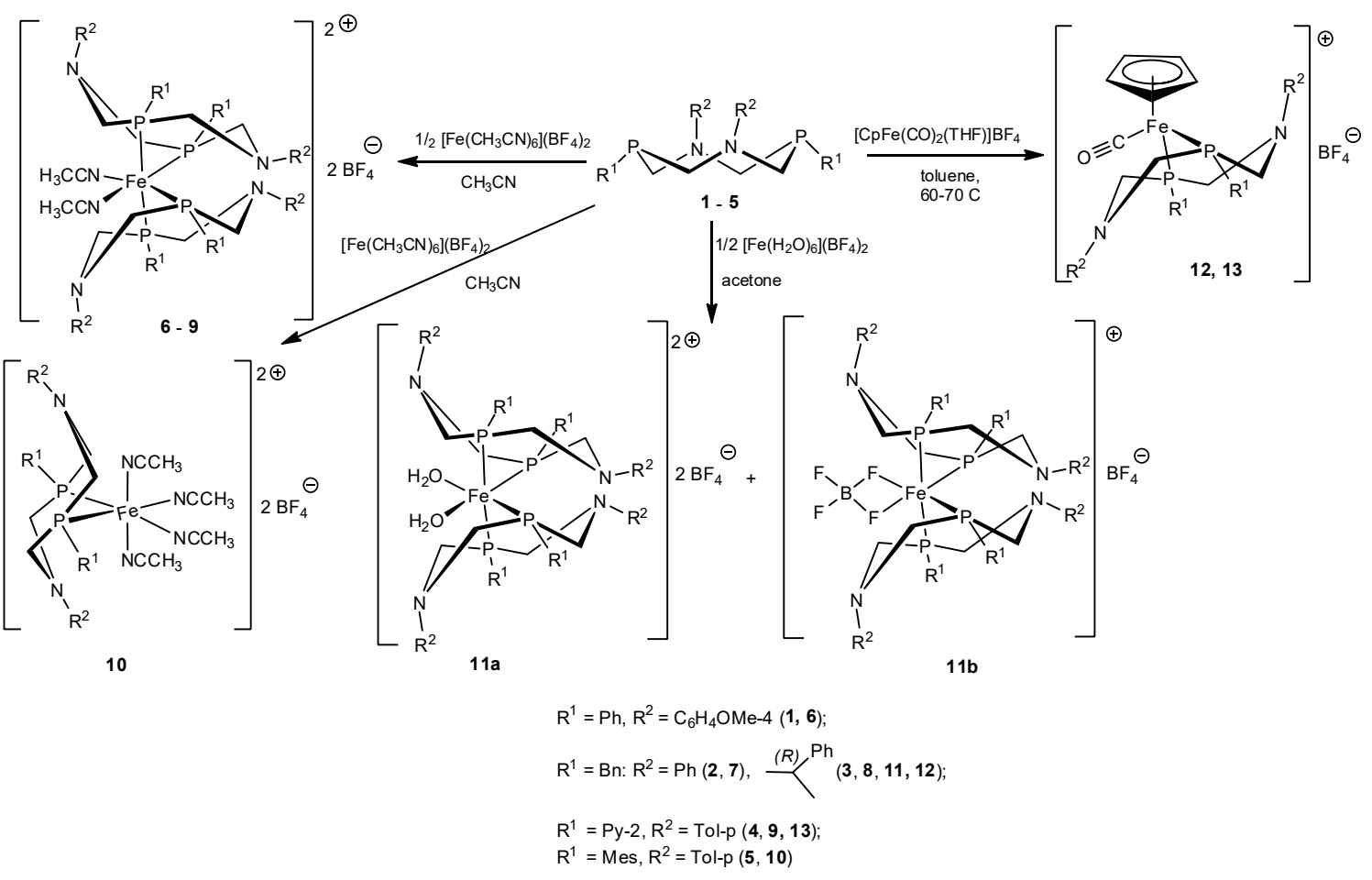

Scheme 1. The synthesis of iron (II) complexes of 1,5-diaza-3,7-diphosphacyclooctanes.

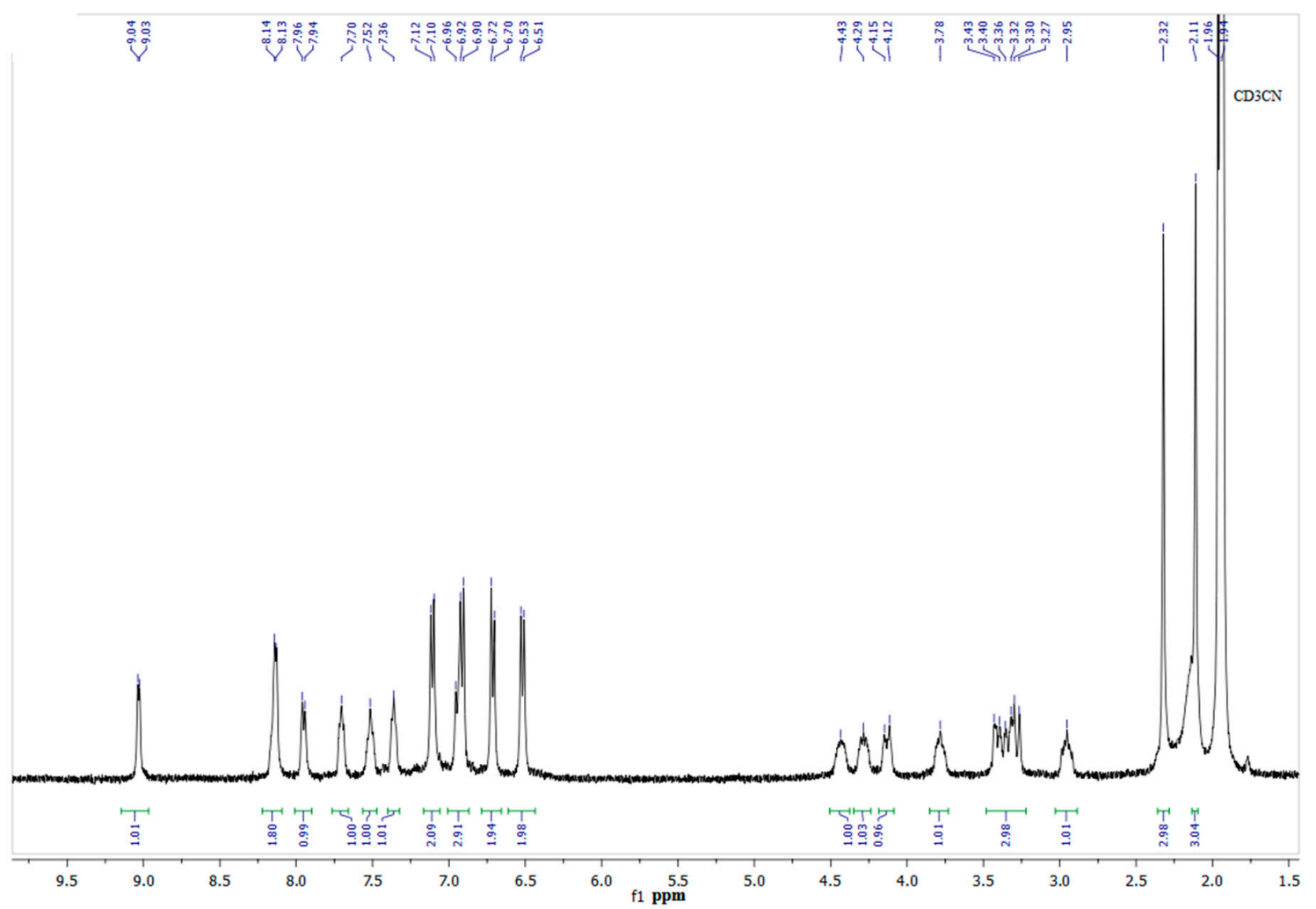

Figure 1. The ${ }^{1} \mathrm{H}-\mathrm{NMR}$ spectrum of complex 9 in $\mathrm{CD}_{3} \mathrm{CN}(400 \mathrm{MHz})$.

The singlets of methyl groups of coordinated acetonitrile molecules were observed near $1.96 \mathrm{ppm}$ in the spectra of complexes 6-9. It indicated that the exchange between coordinated and uncoordinated 
acetonitrile molecules was not fast. However, it should be mentioned that all complexes 6-9 were sensitive to the solvent nature, and their partial decomposition was observed in dimethylformamide (DMF), alcohols, and even in acetone or dichloromethane. In the last solvents, the decomposition was probably caused by the presence of traces of water or hydrogen chloride, which led to the partial substitution of acetonitrile co-ligands, so these ligands might be considered as relatively labile. The solvent sensitivity of these complexes restricted the possibility of their variable-temperature NMR studies.

The proposed structure of the complex 8 was confirmed by X-ray diffraction analysis. A single crystal of $\mathbf{8}$ was grown by the gas-phase diffusion of acetonitrile to the solution of $\mathbf{8}$ in methylene chloride. The iron ion had a distorted octahedral configuration (Figure 2a). The acetonitrile ligands occupied the formally equatorial positions. As a result, bonds P7-Fe and P7B-Fe were formally apical (a bond angle P7-Fe1-P7B is $\left.175.4(1)^{\circ}\right)$, and the other P-Fe bonds were formally equatorial. The selected bond lengths and angles of complex 8 are presented in Table 1. There was not a noticeable difference between the lengths of apical bonds Fe1-P7, Fe1-P7B (2.232(3) and 2.242(3) $\AA$ ) and equatorial bonds Fe1-P3, Fe1-P3B (2.233(3) and 2.246(3) $\AA$ ). The equatorial bond lengths N40-Fe1 and N43-Fe1 were 1.960(10) and $1.940(9) \AA$, the bond angle N40-Fe1-N43 was only $82.9(4)^{\circ}$, whereas the bond angle P3-Fe1-P3B was enlarged up to P3-Fe1-P3B 104.09(1) ${ }^{\circ}$. The similar structure was observed for the previously described cis-[bis(1,5-dibenzyl-3,7-diphenyl-1,5-diaza-3,7-diphosphacyclooctane)di(acetonitrile)-iron(II)] tetrafluoroborate [21].

Table 1. Selected bond lengths and angles of complexes 8 and 11b.

\begin{tabular}{|c|c|c|c|c|}
\hline \multirow{2}{*}{$\begin{array}{c}\text { Parameter } \\
\text { Bond Length (Type) }\end{array}$} & \multicolumn{2}{|c|}{ Complex 8} & \multicolumn{2}{|c|}{ Complex 11b } \\
\hline & Bond & $\mathrm{d}, \AA$ & Bond & $\mathrm{d}, \AA$ \\
\hline \multirow{2}{*}{$\mathrm{d} F e-\mathrm{P}_{\mathrm{a}}$} & Fe1-P7 & $2.232(3)$ & Fe1-P3 & $2.267(3)$ \\
\hline & Fe1-P7B & $2.242(3)$ & Fe1-P3' & $2.267(3)$ \\
\hline \multirow{2}{*}{ d Fe-P $P_{\text {eq }}$} & Fe1-P3 & $2.233(3)$ & Fe1-P7 & $2.209(4)$ \\
\hline & Fe1-P3B & $2.246(3)$ & Fe1-P7' & $2.209(4)$ \\
\hline \multirow{2}{*}{$\mathrm{d} F e-X_{\text {eq }}$} & Fe1-N40 & $1.960(10)$ & Fe1-F1 & $2.050(8)$ \\
\hline & Fe1-N43 & $1.940(9)$ & Fe1-F1' & $2.050(8)$ \\
\hline Bond Angle (Type) & Angle & $\circ$ & Angle & $\circ$ \\
\hline $\mathrm{P}_{\mathrm{a}}-\mathrm{Fe}-\mathrm{P}_{\mathrm{a}}$ & P7-Fe1-P7B & $175.4(1)$ & P3-Fe1-P3' & $176.5(2)$ \\
\hline $\mathrm{P}_{\mathrm{eq}}-\mathrm{Fe}-\mathrm{P}_{\mathrm{eq}}$ & P3-Fe1-P3B & 104.09(1) & P7-Fe1-P7' & 101.1(2) \\
\hline \multirow{4}{*}{$\mathrm{P}_{\mathrm{a}}-\mathrm{Fe}-\mathrm{P}_{\mathrm{eq}}$} & P7-Fe1-P3 & 79.1(1) & P3-Fe1-P7 & $79.96(13)$ \\
\hline & P7B-Fe1-P3B & 79.3(1) & P3'-Fe1-P7' & $79.96(13)$ \\
\hline & P7B-Fe1-P3 & $98.5(3)$ & P3-Fe1-P7' & $102.28(14)$ \\
\hline & P7-Fe1-P3B & $97.4(1)$ & P3'-Fe1-P7 & $102.28(14)$ \\
\hline$X_{\text {eq }}-F e-X_{e q}$ & N40-Fe1-N43 & $82.9(4)$ & F1-Fe1-F1' & $70.1(4)$ \\
\hline \multirow{4}{*}{$\mathrm{X}-\mathrm{Fe}-\mathrm{P}_{\mathrm{a}}$} & N40-Fe1-P7B & $93.5(3)$ & F1-Fe1-P3 & $85.4(3)$ \\
\hline & N43-Fe1-P7 & $94.0(3)$ & $\mathrm{F} 1^{\prime}-\mathrm{Fe} 1-\mathrm{P} 3^{\prime}$ & $85.4(3)$ \\
\hline & N40-Fe1-P7 & $89.6(3)$ & F1-Fe1-P3' & $91.7(3)$ \\
\hline & N43-Fe1-P7B & $89.8(3)$ & F1'-Fe1-P3 & $91.7(3)$ \\
\hline \multirow{4}{*}{$\mathrm{X}-\mathrm{Fe}-\mathrm{P}_{\mathrm{eq}}$} & N40-Fe1-P3 & $164.0(3)$ & F1-Fe1-P7' & $159.5(2)$ \\
\hline & N43-Fe1-P3B & $165.7(3)$ & F1'-Fe1-P7 & $159.5(2)$ \\
\hline & N40-Fe1-P3B & $88.6(3)$ & F1-Fe1-P7 & $95.9(2)$ \\
\hline & N43-Fe1-P3 & $86.6(3)$ & F1'-Fe1-P7' & $95.9(2)$ \\
\hline
\end{tabular}




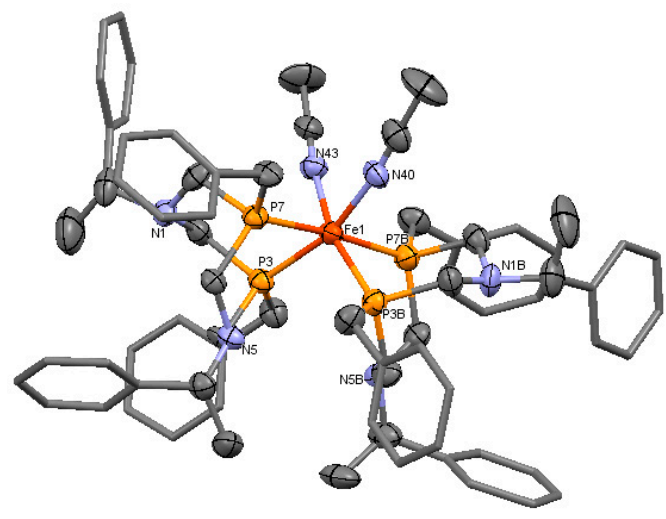

(a)

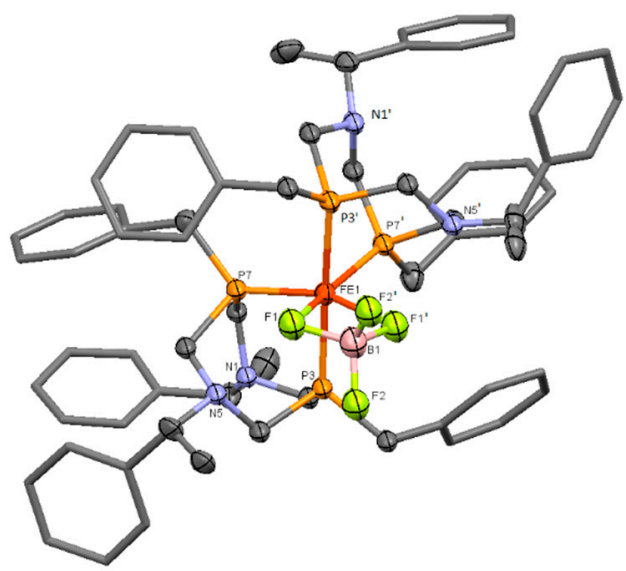

(b)

Figure 2. (a) The molecular structure of the cation of the complex 8. Hydrogen atoms, anions $\mathrm{BF}_{4}$, and solvate molecules (acetonitrile) were omitted for clarity; Bond distances Fe1-P3 2.233(3), Fe1-P7 2.232(3), Fe1-P3B 2.246(3), Fe1-P7B 2.242(3), Fe1-N40 1.960(10), Fe1-N43 1.940(9) A, (b) The molecular structure of the cation of the complex 11b. Hydrogen atoms, disordered anions, and solvate molecules were omitted for clarity. Bond distances Fe1-P3 2.267(3), Fe1-P7 2.209(4), Fe1-F1 2.050(8) A.

Both diazadiphosphacyclooctane ligands $(\mathrm{N}(1) \mathrm{P}(3) \mathrm{N}(5) \mathrm{P}(7)$ and $\mathrm{N}(1 \mathrm{~B}) \mathrm{P}(3 \mathrm{~B}) \mathrm{N}(5 \mathrm{~B}) \mathrm{P}(7 \mathrm{~B})$ ) had chair-boat conformations, so the substituents on nitrogen atoms in the chair and boat parts of the heterocycles were in an essentially different environment. That explained the nonequivalence of these substituents in NMR spectra. It should be mentioned that the high asymmetry of the complex and the nonequivalence of two halves of the ligand cycle had to take place even in the case of conformational exchange between two chair-boat conformations of diazadiphosphacyclooctane. The endocyclic nitrogen atoms of the boat parts of both ligands were in the proximity to the iron ion (the distances $\mathrm{Fe}$ ... N5 and Fe ... N5B are 3.552(8) and 3.566(8) Å respectively). This arrangement was favorable for the secondary interactions, similar to ones observed in natural hydrogenases [3].

The interaction of hexa(acetonitrile)iron (II) tetrafluoroborate with 1,5-diaza-3,7-diphosphacyclooctane 5 bearing bulky mesityl groups on phosphorus atoms led only to monoligand P,P-chelate complex $\left[\mathrm{LFe}\left(\mathrm{CH}_{3} \mathrm{CN}\right)_{4}\right]^{2+}\left(\mathrm{BF}_{4}\right)_{2}{ }^{-} \mathbf{1 0}(\mathrm{L}=5)($ Scheme 1$)$, even in the presence of the excess of the ligand. The exclusive formation of complexes with metal-ligand ratio 1:1 has been earlier shown for 1,5-diaza-3,7-diphosphacyclooctane with bulky substituents on phosphorus atoms and other transition metal (Pt (II), Pd (II), Ni(II)) derivatives [7,27-29]. Both MALDI and ESI mass-spectra of 10 showed a peak with $\mathrm{m} / \mathrm{z} 621$ corresponding to $[\mathrm{LFe}]^{+}$ion $(\mathrm{L}=10)$. Only one narrow signal at $\delta_{\mathrm{P}} 55.56 \mathrm{ppm}$ was observed in its ${ }^{31} \mathrm{P}-\mathrm{NMR}$ spectrum. Unlike the spectra of the complexes $6-9$, the ${ }^{1} \mathrm{H}-\mathrm{NMR}$ spectrum of $\mathbf{1 0}$ showed only one set of signals for every group of ligand's protons. The spectral pattern was typical for the chair-boat conformation of diazadiphosphacyclooctane ligand in the case of the fast conformational exchange in the NMR time scale in the solutions [29]. The absence of the signal of coordinated acetonitrile molecules indicated also the fast exchange and the lability of acetonitrile co-ligands.

The acetonitrile co-ligands are considered as ones, which form relatively strong coordination bonds with iron (II) ion [21], so in order to obtain the iron complex with less coordinating co-ligands or even coordinationally unsaturated iron complex of 1,5-diaza-3,7-diphosphacyclooctane, the hydrate iron complex was used as the starting reagent in a low-coordinating solvent. Ligand 3 readily reacted with iron (II) tetrafluoroborate hexahydrate $\left[\mathrm{Fe}\left(\mathrm{H}_{2} \mathrm{O}\right)_{6}\right]\left(\mathrm{BF}_{4}\right)_{2}$ in acetone to give a mixture of two bis-ligand cis-complexes 11a and $\mathbf{1 1 b}$ (Scheme 1). In the ${ }^{31} \mathrm{P}-\mathrm{NMR}$ spectrum of the reaction mixture, two pairs of doublets at $\delta_{\mathrm{P}} 38.21$ and $31.03 \mathrm{ppm}\left({ }^{2} J_{\mathrm{PP}} \approx{ }^{2} J_{\mathrm{PP}} \approx 70.7 \mathrm{~Hz}\right)(\mathbf{1 1 a}), 37.30$ and $29.94 \mathrm{ppm}$ $\left({ }^{2} J_{\mathrm{PP}} \approx{ }^{2} J_{\mathrm{PP}} \approx 71.8 \mathrm{~Hz}\right)(\mathbf{1 1 b})$ with a ratio of intensities of 1.4:1 were observed. Nevertheless, after the concentration of the reaction mixture and the crystallization of the residue at $-15^{\circ} \mathrm{C}$, only the minor 
product 11b was isolated as small dark-red crystals in the yield of $41 \%$. The elemental analysis data of $11 \mathbf{b}$ corresponded to the composition $\mathrm{L}_{2} \mathrm{Fe}\left(\mathrm{BF}_{4}\right)_{2}(\mathrm{~L}=3)$. Its mass-spectrum showed peaks with $\mathrm{m} / \mathrm{z}$ 1132 and 1162 corresponding to the ions $\left[\mathrm{L}_{2} \mathrm{Fe}\right]^{+}$and $\left[\mathrm{L}_{2} \mathrm{FeBF}\right]^{+}$. Unexpectedly, the bands of hydroxyl groups were absent in the IR-spectrum of $\mathbf{1 1 b}$, whereas the characteristic very strong broadband of $\mathrm{BF}_{4}$ anion was observed at $1057 \mathrm{~cm}^{-1}$. Two doublets at 37.30 and $29.94 \mathrm{ppm}\left({ }^{2} J_{\mathrm{PP}}={ }^{2} J_{\mathrm{PP}}=71.8 \mathrm{~Hz}\right)$ were observed in its ${ }^{31} \mathrm{P}-\mathrm{NMR}$ spectrum. Like the spectra of complexes $\mathbf{6 - 9}$, the ${ }^{1} \mathrm{H}-\mathrm{NMR}$ spectrum of $\mathbf{1 1 b}$ demonstrated the pairwise nonequivalence of all protons of the heterocyclic fragments, of the benzylic methylene groups, and 1-phenylethyl substituents on nitrogen atoms, which indicated the chair-boat conformations of diazadiphosphacyclooctane rings. The absence of the signals of the coordinated water in the spectrum was in accordance with the data of IR-spectroscopy and confirmed the absence of water co-ligands in the coordination sphere of the iron.

The structure of the complex $\mathbf{1 1 b}$ was finally established by X-ray diffraction analysis. Unfortunately, despite numerous attempts to grow a crystal of satisfactory quality, it was not possible, and the crystal structure of the compound was established with large experimental errors; nevertheless, the structure of the complex cation was established reliably. Therefore, in this work, we presented only the conformation and selected geometry parameters of the cation, but not the crystal structure of this compound. The dark-red single crystal of $\mathbf{1 1 b}$ was grown by the gas-phase diffusion of acetone to the solution of $\mathbf{1 1} \mathbf{b}$ in methylene chloride. It should be mentioned that the crystal is an acetone solvate and contains an undetermined solvent. Molecule $\mathbf{1 1} \mathbf{b}$ appeared to be a bis-ligand monocationic complex of the composition $\left[\mathrm{L}_{2} \mathrm{Fe}\left(\mathrm{BF}_{4}\right)\right]^{+} \mathrm{BF}_{4}^{-}$, where two fluorine atoms of one of the tetrafluoroborate unit were included in the coordination sphere of the iron ion and occupied two pseudo-equatorial positions (Figure 2b). A similar coordination mode was described for the complexes of bis- and tetrakis-phosphines with iron (II) sulfate and carbonate [30,31], but for the low-coordinating tetrafluoroborate anion, it was unexpected. The molecule $\mathbf{1 1 b}$ in this crystal was on the special position on the two-fold axis 2 (atoms Fe and B lied on the two-fold axis 2). In the unit cell of the crystal, $888 \AA^{3}$ free volumes remained, in which other solvate molecules could not be identified. As a result, the refinement of the structure was carried out using the SQUEEZE procedure. It should be mentioned that a simultaneous TG/DSC analysis of the single crystals of $\mathbf{1 1} \mathbf{b}$ showed a loss of two water molecules and a half of acetone molecule per one molecule of the complex in the temperature range 60-138 ${ }^{\circ} \mathrm{C}$ (Figure S26, Supplementary Materials), so the undetermined disordered solvent was the water and acetone.

The central iron ion had the strongly distorted octahedral configuration: the dihedral angle between $\mathrm{P}(7)-\mathrm{Fe}-\mathrm{P}\left(7^{\prime}\right)$ and $\mathrm{F}(1)-\mathrm{Fe}-\mathrm{F}\left(1^{\prime}\right)$ planes was $20(1)^{\circ}$, and the bond angles $\mathrm{P}(7)-\mathrm{Fe}-\mathrm{P}\left(7^{\prime}\right)$ and $\mathrm{F}(1)-\mathrm{Fe}-\mathrm{F}\left(1^{\prime}\right)$ were $101.1(2)$ and $70.4(4)^{\circ}$, respectively, $\left(\mathrm{P}\left(7^{\prime}\right)\right.$ and all atoms with ' were symmetry-related atoms, symmetry operation $2-x, 1-x+y, 1-z)$. The bond angle $P(3)-F e-P\left(3^{\prime}\right)$ was 176.5(2) . $\mathrm{P}, \mathrm{P}$-chelating diazadiphosphacyclooctane ligands had chair-boat conformations; phosphorus atoms of every ligand coordinated the iron atom in pseudo-equatorial and pseudo-apical positions. Bond lengths of equatorial bonds Fe1-P7 were 2.209(4), and the axial bonds Fe1-P3 were 2.267(3) $\AA$ (the selected bond lengths and angles of complex $\mathbf{1 1 b}$ are presented in Table 1). Nitrogen atoms of the boat parts of the heterocycles were directed to the coordinated tetrafluoroborate fragment so that they were in the proximity, both to the central ion (the shortest distance Fe1 ... N5 was 3.314(11) $\AA$ ) and to the coordinated fluorine atoms (the shortest distance F ... N was only 2.59(2) $\AA$ and less than a sum of van der Waals radii). Their lone electron pairs were directed to the metal iron. This structure might be favorable for the small molecules activation due to the secondary interactions of the metal-coordinated substrates with amine centers of the ligands. The comparison of the structural parameters of complexes $\mathbf{8}$ and $\mathbf{1 1} \mathrm{b}$ showed more noticeable distortion of the octahedral geometry of iron ion in $\mathbf{1 1 b}$, namely, the small value of F1-Fe-F1' bond angle and some lengthening of apical $\mathrm{Fe}-\mathrm{P}$ bonds in comparison with equatorial ones (2.267(3) vs. 2.209(4) $\AA$ ), whereas Fe-P distances of complex 8 varied in the narrow range of 2.232(3)-2.246(3) $\AA$ (Table 1). The bond lengths Fe-F were close $(2.050(9) \AA)$. The bonds B-F with the coordinated fluorine atoms were slightly longer 
than the corresponding bonds with uncoordinated ones (1.49(2) $\AA$ vs. 1.39(2) $\AA$ ). The Fe-F bond lengths were within the typical range of few known $\mathrm{BF}_{4}$-ligated iron (II) complexes (1.96-2.26 $\mathrm{A}$ ), which contained only terminally $\eta^{1}$-coordinated tetrafluoroborate anions [32-39]. The most of known complexes-containing bidentate $\kappa^{2}$-bound tetrafluoroborate ligands were silver (I) complexes with weakly coordinated $\mathrm{BF}_{4}$ anions, where the Ag-F distances were relatively long (2.79-3.01 $\AA$ ) [40-43]. Only two examples of an almost covalent $\kappa^{2}-\mathrm{F}_{2} \mathrm{BF}_{2}$ bonding of tetrafluoroborate anion had been described, namely, the silver (I) complex of cyclodextrine-based diphosphine, where $\mathrm{BF}_{4}{ }^{-}$counterion lied deep inside the cavity, and Ag-F distances were only 2.53-2.62 $\AA$ [44], and dimolibdenum complex $\left[\mathrm{Mo}_{2} \mathrm{Cp}_{2}\left(\mathrm{k}^{2}-\mathrm{F}_{2} \mathrm{BF}_{2}\right)\left(\mu-\mathrm{PPh}_{2}\right)_{2}(\mathrm{CO})\right]\left(\mathrm{BF}_{4}\right)$, which showed close and short Mo-F distances (2.18(1) $\left.\mathrm{A}\right)$ [45]. These values were quite close to the metal-fluorine distances measured for related $\eta^{1}-\mathrm{FBF}_{3}$ coordinated tungsten and molybdenum complexes [45]. According to these structural criteria, namely, the usual lengths of two Fe-F bonds in the cation of $\mathbf{1 1 b}$ and a small difference between them, the $\mathrm{Fe} / \mathrm{BF}_{4}$ interaction might be considered as relatively strong and close to the covalent one.

The complex 11a was not isolated, but most probably it was the corresponding dihydrate complex with uncoordinated tetrafluoroborate anions; the easy replacement of two water ligands by bidentate sulfate or carbonate ligand from the outer sphere was described for the iron (II) complexes of 1,5-di[di (hydroxymethyl)phosphinomethyl]-3,7-di(hydroxymethyl)-1,5-diaza-3,7-diphosphacyclooctane [30].

The attempt to register NMR spectra of $11 \mathrm{~b}$ in $\mathrm{CD}_{3} \mathrm{CN}$ showed the fast change of the solution color from red to yellow and the appearance of the signals of corresponding bis-acetonitrile complex 8 (multiplets at 25.6 and $34.2 \mathrm{ppm}$ ) along with other signals in close ranges, which presumably corresponded to the products of the incomplete ligand replacement. The possibility of the exchange of tetrafluoroborate ligand to acetonitrile led to the attempt to synthesize complex 8 directly from the more accessible and less sensitive iron (II) tetrafluoroborate hexahydrate. Its interaction with the ligand 3 in acetonitrile indeed led finally to the complex 8, but the reaction was very slow, and its completion required about 50 days vs. $12 \mathrm{~h}$ in the case of starting from $\left[\mathrm{Fe}\left(\mathrm{CH}_{3} \mathrm{CN}\right)_{6}\right]\left(\mathrm{BF}_{4}\right)_{2}$, so this route was inadvisable.

The interaction of P-benzyl-substituted ligand 3 with cyclopentadienyldicarbonyl(tetrahydrofuran) iron (II) tetrafluoroborate in toluene at ambient temperature for 1 day smoothly led to the replacement of tetrahydrofuran (THF) and one of the carbonyl ligand by the diphosphine ligand 3 and to the formation of cationic complex 12 (Scheme 1) in a yield of $82 \%$. A similar complex containing chloride counter-ion was isolated in relatively low yield (20\%) during the early stages of the photolysis of a mixture of $\mathrm{CpFe}(\mathrm{CO})_{2} \mathrm{Cl}$ and 1,5-dibenzyl-3,7-diphenyl-1,5-diaza-3,7-diphosphacyclooctane, whereas the final and main product of the photolysis was the complex $\mathrm{CpFe}\left(\mathrm{P}^{\mathrm{Ph}}{ }_{2} \mathrm{~N}_{2}{ }_{2}\right) \mathrm{Cl}$ [22]. The reaction of the ligand 4 with $\left[\mathrm{CpFe}(\mathrm{CO})_{2}(\mathrm{THF})\right] \mathrm{BF}_{4}{ }^{-}$proceeded slowly, probably due to a decreased nucleophilicity of phosphorus atoms bearing relatively electron-withdrawing pyridyl substituents. The completion of the reaction required the heating of the reaction mixture at $60-70{ }^{\circ} \mathrm{C}$ for 4 days, and the formation of the analogous complex 13 (Scheme 1) was complicated by the precipitation of a large amount of low-soluble and paramagnetic dark resin, so the yield of $\mathbf{1 3}$ was only $9 \%$. Presumably, the prolonged heating led to a loss of its carbonyl ligand. According to elemental analysis data, the complexes 12 and $13 \mathrm{had}$ the composition [CpFeL(CO)] ${ }^{+} \mathrm{BF}_{4}{ }^{-}$, and their ESI mass-spectra showed the peaks of corresponding cations $[\mathrm{CpFeL}(\mathrm{CO})]^{+}(\mathrm{L}=3,4)$ with $\mathrm{m} / z$ 687.3 and 633.4, respectively. Two bands of the carbonyl group vibrations at 1940 and $1950-1951 \mathrm{~cm}^{-1}$ were observed in the IR spectra of 12 and 13. In the ${ }^{31} \mathrm{P}-\mathrm{NMR}$ spectrum of 13, one narrow signal at $59.14 \mathrm{ppm}$ was observed, whereas the spectrum of 12 showed two close doublets of $\mathrm{AB}$ system at 55.55 and $56.27 \mathrm{ppm}\left({ }^{2} J_{\mathrm{PP}}=116.4 \mathrm{~Hz}\right)$ because two phosphorus atoms were nonequivalent due to the presence of the chiral substituents on nitrogen atoms [46]. In the ${ }^{1} \mathrm{H}-\mathrm{NMR}$ spectrum of $\mathbf{1 3}$, the nonequivalence of the $p$-tolyl substituents on nitrogen atoms and the pairwise nonequivalence of the methylene groups in the heterocyclic fragment were observed as a result of the chair-boat conformation of the diazadiphosphacyclooctane ligand. In the ${ }^{1} \mathrm{H}-\mathrm{NMR}$ spectrum of $\mathbf{1 2}$, the presence of chiral substituents on nitrogen atoms led additionally to the nonequivalence of benzyl substituents on phosphorus atoms and to the nonequivalence of all 
four methylene groups of the chair-boat diazadiphosphacyclooctane fragment, which formed complex overlapped multiplets. The protons of cyclopentadienyl ligands were registered as a singlet at $5.18 \mathrm{ppm}$ for $\mathbf{1 2}$ and as a triplet at $5.05 \mathrm{ppm}\left({ }^{2} \mathrm{~J}_{\mathrm{PH}}=1.4 \mathrm{~Hz}\right)$ for $\mathbf{1 3}$.

The redox properties of synthesized iron complexes 6-13 were studied by the cyclic voltammetry in MeCN. The results are presented in Table 2 and Figure 3. One reduction and oxidation peaks were observed for all iron complexes. One irreversible reduction peak, as we supposed, corresponding to FeII/I couple, was observed on cyclic voltammograms (CVs) at range from -1.37 to $-1.74 \mathrm{~V}$ (for complexes 6-10) and depended on substituents at phosphorus and nitrogen atoms of ligands. The reversible oxidation peak corresponding FeII/III couple was observed at $0.25-0.34 \mathrm{~V}$ in these cases. In the case of complexes 12 and 13, slightly negative shift to $-1.60-1.80 \mathrm{~V}$ of reduction potential (vs. bis-chelated complexes 6-9) and irreversible oxidation peaks at 1.10-1.23 V were observed on CVs.

Table 2. Electrochemical data for iron complexes 6-13 in $\mathrm{MeCN}$ (potentials vs. $\mathrm{Ag} / \mathrm{AgCl}$ reference electrode).

\begin{tabular}{ccc}
\hline Complex & Reduction Potential, V & Oxidation Potential, V \\
\hline $\mathbf{6}$ & -1.74 & 0.34 \\
$\mathbf{7}$ & -1.50 & 0.30 \\
$\mathbf{8}$ & -1.48 & 0.25 \\
$\mathbf{9}$ & -1.37 & 0.30 \\
$\mathbf{1 0}$ & -1.64 & 0.32 \\
$\mathbf{1 2}$ & -1.80 & 1.23 \\
$\mathbf{1 3}$ & -1.60 & 1.10 \\
\hline
\end{tabular}

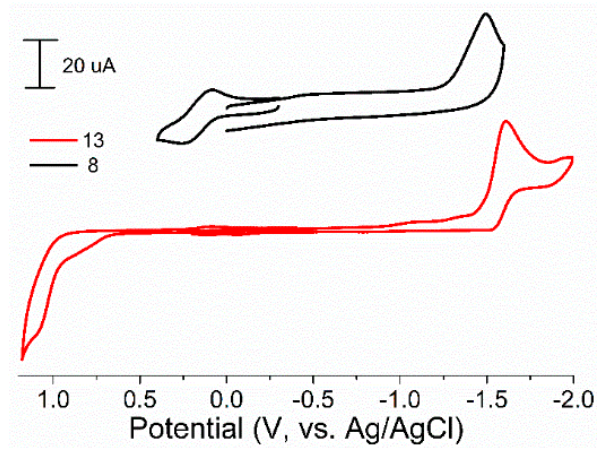

Figure 3. Cyclic voltammograms for complexes 8 and 13 in MeCN. Conditions: working electrode-glassy carbon, auxiliary electrode- $\mathrm{Pt}$, supporting electrolyte- $\mathrm{Bu}_{4} \mathrm{NBF}_{4}$.

\section{Discussion}

1,5-Diaza-3,7-diphosphacyclooctanes 1-4 with relatively small phenyl, benzyl, and pyridin-2-yl substituents on phosphorus atoms reacted with hexa(acetonitrile)iron (II) tetrafluoroborate in acetonitrile as $\mathrm{P}$,P-chelating ligands to give bis-ligand cis-complexes $\left[\mathrm{L}_{2} \mathrm{Fe}\left(\mathrm{CH}_{3} \mathrm{CN}\right)_{2}\right]^{2+}\left(\mathrm{BF}_{4}\right)_{2}{ }^{-}(6-9)$, whereas the P-mesityl-substituted ligand 5 formed only monoligand P,P-complex $\left[\mathrm{LFe}\left(\mathrm{CH}_{3} \mathrm{CN}\right)_{4}\right]^{2+}$ $\left(\mathrm{BF}_{4}\right)_{2}{ }^{-}(\mathbf{1 0})$. The interaction of the ligand 3 with hexahydrate of iron (II) tetrafluoroborate in acetone unexpectedly led to a bis-ligand cationic complex of the composition $\left[\mathrm{L}_{2} \mathrm{Fe}\left(\mathrm{BF}_{4}\right)\right]^{+}$ $\mathrm{BF}_{4}^{-}(\mathbf{1 1 b})$, where two fluorine atoms of one of the tetrafluoroborate unit were included into the coordination sphere of the iron ion and occupied two pseudo-equatorial positions. 1,5-diaza-3,7-diphosphacyclooctane ligands were able to replace tetrahydrofurane and one of the carbonyl ligands of cyclopentadienyldicarbonyl(tetrahydrofuran)iron (II) tetrafluoroborate to form heteroligand complexes 12 and 13 of the composition $[\mathrm{CpFeL}(\mathrm{CO})]^{+} \mathrm{BF}_{4}{ }^{-}$. The diazadiphosphacyclooctane ligands of all complexes adopted chair-boat conformations so that their nitrogen atoms were in close proximity to the central iron ion. In spite of the favorable disposition of the metal center and pendant amine 
centers, the redox properties of the obtained complexes (in particular, the presence of the irreversible reduction peaks) were not promising for the application of these complexes as electrocatalysts.

\section{Materials and Methods}

\subsection{General}

All the reactions and manipulations with phosphines 1-5 were carried out under a dry argon atmosphere using standard vacuum-line techniques. All manipulations with complexes 6-13, excluding the electrochemical measurements, were carried out under normal conditions without inert atmosphere. Solvents were purchased from Acros Organics (Geel, Belgium) and were purified, dried, deoxygenated, and distilled before use. Iron (II) tetrafluoroborate hexahydrate, hexa(acetonitrile)iron (II) tetrafluoroborate and cyclopentadienyldicarbonyl(tetrahydrofuran)iron (II) tetrafluoroborate were purchased from Sigma-Aldrich (St. Louis, MO, USA) and used as received.

ESI $_{\text {pos }}$ MS were recorded with an AmazonX (Bruker Daltonics GmbH, Bremen, Germany) spectrometer at a capillary voltage of 4500 V. DataAnalysis 4.0 (Bruker Daltonics GmbH, Bremen, Germany) program was used to process the mass spectrometry data. MALDI MS was recorded with an Ultraflex III TOF/TOF (Bruker Daltonics, Germany) spectrometer on the $p$-nitroaniline (pNA) matrix. FlexAnalysis 3.0 (Bruker Daltonics $\mathrm{GmbH}$, Bremen, Germany) program was used to process the mass spectrometry data. The mass spectra are reported as $m / z$ values. ${ }^{1} \mathrm{H}-\mathrm{NMR}(400 \mathrm{MHz}$ and $600 \mathrm{MHz}$ ) and ${ }^{31} \mathrm{P}-\mathrm{NMR}(162$ and $242 \mathrm{MHz})$ spectra were obtained with Bruker Avance-DRX 400 (BrukerBioSpin, Billerica, MA, USA) and Bruker Avance-600 spectrometers (BrukerBioSpin, Billerica, MA, USA). The chemical shifts are reported in ppm relative to $\mathrm{SiMe}_{4}\left({ }^{1} \mathrm{H}\right.$, internal standard) and $85 \%$ $\mathrm{H}_{3} \mathrm{PO}_{4}$ (aq) ${ }^{31} \mathrm{P}$, external standard). The coupling constants $(J)$ are reported in $\mathrm{Hz}$. The IR spectra were obtained on a spectrometer "Vector-22" (Bruker Optics GmbH, Bremen, Germany) in the range $400-4000 \mathrm{~cm}^{-1}$ in Nujol mulls. Determination of the CHN content was carried out on CHN analyzer "CHN-3 KBA". The determination of the phosphorus content was provided by combustion in an oxygen stream. Simultaneous thermogravimetry and differential scanning calorimetry (TG/DSC) analysis of samples of $\mathbf{1 1 b}$ (solvate) $(10.7 \mathrm{mg}$ ) were performed using the STA 449F1 Jupiter (Netzsch, Selb, Germany) thermoanalyzer (in the range of temperatures from 40 to $200{ }^{\circ} \mathrm{C}$ in aluminum crucible under a dynamic atmosphere of argon $75 \mathrm{~mL} / \mathrm{min}$ ). The heating rate was $10^{\circ} \mathrm{C} / \mathrm{min}$.

Starting phosphines 1 [47], 2 [48], and 4 [2] were prepared according to the literature procedures.

\subsection{X-ray Crystallography Data}

The data of $\mathbf{8}$ were collected on a Bruker SmartApex II (Bruker AXS GmbH, Karlsruhe, Germany) using the $\omega$-scan mode, and the data of $\mathbf{1 1 b}$ were collected on a Bruker KappaApex II diffractometer (Bruker AXS GmbH, Karlsruhe, Germany) $\left(\lambda\left(\mathrm{MoK}_{\alpha}\right)=0.71073 \AA\right)$, at temperature $100(2) \mathrm{K}$. The performance mode of the sealed X-ray tube was $50 \mathrm{kV}, 30 \mathrm{~mA}$. A suitable crystal of appropriate dimensions was mounted on a glass fiber in a random orientation. Data collection: images were indexed and integrated using the APEX3 data reduction package (v2018.7-2, Bruker AXS, Madison, WI, USA). Final cell constants were determined by the global refinement of reflections from the complete data set. Data were corrected for systematic errors and absorption using SADABS-2016/2 (v2016-2, Bruker AXS, Madison, WI, USA). XPREP-2014/2 (v2014-2, Bruker AXS, Madison, WI, USA) and the Assign Space group routine of WinGX-2018.3 (v2018-3, Bruker AXS, Madison, WI, USA) were used for the analysis of systematic absences and space-group determination. The structures were solved by the direct method using SHELXT-2018/2 (v2018-2, Bruker AXS, Madison, WI, USA) [49] and refined by the full-matrix least-squares on $F^{2}$ using SHELXL-2018/3 (v2018-3, Bruker AXS, Madison, WI, USA) [50] and refined by the full-matrix least-squares on $F^{2}$ using SHELXL-2018/3 (v2018-3, Bruker AXS, Madison, WI, USA) [50]. Calculations were mainly performed using the WinGX-2018.3 suite of programs [51]. Non-hydrogen atoms were refined anisotropically. The hydrogen atoms were inserted 
at the calculated positions and treated as riding atoms. The absolute structure of crystals was confirmed by the Flack parameter [52].

\subsubsection{Crystal Data and Structure Refinement for Compound 8}

$\mathrm{C}_{72} \mathrm{H}_{86} \mathrm{FeN}_{6} \mathrm{P}_{4}{ }^{2+}, 2\left(\mathrm{BF}_{4}^{-}\right), 2\left(\mathrm{C}_{2} \mathrm{H}_{3} \mathrm{~N}\right)^{-} ; M=1470.93$, orthorhombic, space group $P 2{ }_{1}{ }_{2} 2_{1}$, $a=13.7178(14), b=20.452(2), c=27.659(3) \AA, V=7759.9(14) \AA^{3}, Z=4, D_{\text {calc }}=1.259 \mathrm{~g} \mathrm{~cm}^{-3}$; $\mu\left(\mathrm{Mo}_{\mathrm{K} \alpha}\right)=0.342 \mathrm{~mm}^{-1} ; \Theta_{\mathrm{Max}}=25.8^{\circ}, 134,467$ reflections were measured, 14,690 were independent reflections. Final $R_{1}=0.0791, R_{\mathrm{W}}=0.1537$, goodness of fit 1.007 for 7289 reflections with $I \geq 2 \sigma(I)$, and $R_{1}=0.2051, R_{\mathrm{W}}=0.2081$ for all reflections; flack parameter (absolute structure parameter) $0.006(12)$.

\subsubsection{Crystal Data and Structure Refinement for Compound 11b}

$3\left(\mathrm{C}_{68} \mathrm{H}_{68} \mathrm{BF}_{4} \mathrm{FeN}_{4} \mathrm{P}_{4}^{+}\right), 2\left(\mathrm{BF}_{4}^{-}\right), 15\left(\mathrm{C}_{3} \mathrm{H}_{6} \mathrm{O}\right),[+$ solvent $]$, one $\mathrm{BF}_{4}^{-}$anion was not solved; $M=4704.49$, trigonal, space group P321, $a=b=22.651(2), c=15.3431(17) \AA, V=6817.4(16) \AA^{3}$, $Z=1, D_{\text {calc }}=1.146 \mathrm{~g} \mathrm{~cm}^{-3} ; \mu\left(\mathrm{Mo}_{\mathrm{K} \alpha}\right)=0.297 \mathrm{~mm}^{-1} ; 29,199$ reflections were measured, 8934 were independent reflections. Final $R_{1}=0.1040, R_{\mathrm{W}}=0.2221$ for 4109 reflections with $I \geq 2 \sigma(I)$, and $R_{1}$ $=0.2191, R_{\mathrm{W}}=0.2794$ for all reflections, goodness of fit 0.978 , flack parameter (absolute structure parameter) $-0.04(4)$. Organometallic cation was on a special position on the two-fold axis; $\mathrm{BF}_{4}$ anion was on a special position on the trifold axis; molecules disordered on 6 positions $\mathrm{BF}_{4}{ }^{-}$anion were disordered by two-fold and trifold axes and were not solved from different Fourier maps, and one of the solvate molecules of acetone was on a special position on the two-fold axis. In this crystal, the total potential solvent-accessible void volume (SOLV-Map Value) $926 \AA^{3}$ was found, but solvate molecules and those disordered on 6 positions of $\mathrm{BF}_{4}{ }^{-}$anion were not found from the different Fourier maps of electron density, and the final stages of structure refinement were performed using the SQUEEZE procedure of program PLATON [53].

CCDC 2000581 (8), CCDC 2000582 (11b) contained the crystallographic data. These data could be obtained free of charge via www.ccdc.cam.ac.uk/conts/retrieving.html (or from the Cambridge Crystallographic Data Centre, 12 Union Road, Cambridge CB2 1EZ, UK; Fax: (+44)-1223-336-033; or deposit@ccdc.cam.uk).

\subsection{Electrochemical Measurements}

Cyclic voltammetry measurements were performed with an E2P potentiostat of BASi Epsilon (USA) composed of a measuring block, a Dell Optiplex 320 computer with an installed EpsilonES-USB-V200 program, and a C3 electrochemical cell. A stationary glassy-carbon electrode (with a diameter of $3.0 \mathrm{~mm}$ ) was used as a working electrode. $\mathrm{Ag} / \mathrm{AgCl}$ was used as a reference electrode. A platinum wire of $0.5 \mathrm{~mm}$ diameter was used as an auxiliary electrode. Measurements were performed under an inert argon atmosphere.

3,7-Dibenzyl-1,5-di(1'-(R)-phenylethyl)-1,5-diaza-3,7-diphosphacyclooctane (3). 1-(R)-phenylethylamine $(0.83 \mathrm{~g}, 6.85 \mathrm{mmol})$ in dry ethanol $(7 \mathrm{~mL})$ was added to a solution of bis(hydroxymethyl)benzylphosphine, obtained by the stirring of the mixture of benzylphosphine $(0.85 \mathrm{~g}, 6.85 \mathrm{mmol})$ and paraformaldehyde $(0.41 \mathrm{~g}, 13.70 \mathrm{mmol})$ at $100-110^{\circ} \mathrm{C}$ up to homogenization in dry ethanol $(8 \mathrm{~mL})$. The reaction mixture was stirred at $70-80^{\circ} \mathrm{C}$ for $6 \mathrm{~h}$ and cooled. The precipitate formed was filtered off, washed with ethanol, and dried for $5 \mathrm{~h}$ at $2 \cdot 10^{-2}$ torr to give 3 as a white powder $(1.07 \mathrm{~g}, 58 \%)$. M.p. $130-132{ }^{\circ} \mathrm{C}$. ${ }^{1} \mathrm{H}-\mathrm{NMR}\left(\mathrm{CDCl}_{3}\right): \delta 1.14\left(\mathrm{~d},{ }^{3} \mathrm{~J}_{\mathrm{HH}}=6.4 \mathrm{~Hz}, 6 \mathrm{H}, \mathrm{CH}_{3}\right), 2.06\left(\mathrm{~d},{ }^{2} J_{\mathrm{HH}}=13.0 \mathrm{~Hz}, 2 \mathrm{H}, \mathrm{P}-\mathrm{CH}_{2}-\mathrm{Ph}\right), 2.19$ (br. d, $\left.{ }^{2} J_{\mathrm{HH}}=13.0 \mathrm{~Hz}, 2 \mathrm{H}, \mathrm{P}-\mathrm{CH}_{2}-\mathrm{Ph}\right), 2.91\left(\mathrm{~d},{ }^{2} J_{\mathrm{HH}}=14.8 \mathrm{~Hz}, 2 \mathrm{H}, \mathrm{P}-\mathrm{CH}_{2}-\mathrm{N}\right), 3.06\left(\mathrm{~d},{ }^{2} J_{\mathrm{HH}}=14.4 \mathrm{~Hz}\right.$, $2 \mathrm{H}, \mathrm{P}-\mathrm{CH}_{2}-\mathrm{N}$ ), 3.27 (br. d, ${ }^{2} J_{\mathrm{HH}}=14.4 \mathrm{~Hz}, 2 \mathrm{H}, \mathrm{P}-\mathrm{CH}_{2}-\mathrm{N}$ ), 3.69 (br. d, ${ }^{2} J_{\mathrm{HH}}=14.8 \mathrm{~Hz}, 2 \mathrm{H}, \mathrm{P}_{-} \mathrm{CH}_{2}-\mathrm{N}$ ), $4.64\left(\mathrm{q},{ }^{3} J_{\mathrm{HH}}=6.4 \mathrm{~Hz}, 2 \mathrm{H}, \mathrm{CH}(\mathrm{Me}) \mathrm{Ph}\right), 7.07\left(\mathrm{t},{ }^{3} J_{\mathrm{HH}}=7.8 \mathrm{~Hz}, 2 \mathrm{H}, \mathrm{H}_{\mathrm{ar}}\right), 7.10-7.26\left(\mathrm{~m}, 14 \mathrm{H}, \mathrm{H}_{\mathrm{ar}}\right), 7.48$ $\left(\mathrm{d},{ }^{3} \mathrm{~J}_{\mathrm{HH}}=7.8 \mathrm{~Hz}, 4 \mathrm{H}, \mathrm{H}_{\mathrm{ar}}\right) .{ }^{31} \mathrm{P}\left\{{ }^{1} \mathrm{H}\right\} \mathrm{NMR}\left(\mathrm{CDCl}_{3}\right): \delta_{\mathrm{P}}-67.54$ (s). Anal. Calc. for $\mathrm{C}_{34} \mathrm{H}_{40} \mathrm{P}_{2} \mathrm{~N}_{2}(538.64)$ : C 75.81, H 7.49, N 5.20, P 11.50\%. Found: C 75.60, H 7.57, N 5.16, P 11.61\%. 
3,7-Dimesityl-1,5-di(p-tolyl)-1,5-diaza-3,7-diphosphacyclooctane (5). 5 was prepared like 3 from mesitylphosphine $(0.91 \mathrm{~g}, 5.99 \mathrm{mmol})$, paraformaldehyde $(0.36 \mathrm{~g}, 12.00 \mathrm{mmol})$, and $p$-toluidine $(0.64 \mathrm{~g}, 5.99 \mathrm{mmol})$. The reaction time was $10 \mathrm{~h}$, and the yield of 5 was $1.05 \mathrm{~g}(62 \%)$. M.p. $>200{ }^{\circ} \mathrm{C}$ (decomp.). ${ }^{1} \mathrm{H}-\mathrm{NMR}\left(\mathrm{CDCl}_{3}\right): \delta 2.18\left(\mathrm{~s}, 6 \mathrm{H}, \mathrm{NC}_{6} \mathrm{H}_{4} \mathrm{CH}_{3}\right), 2.34\left(\mathrm{~s}, 6 \mathrm{H}, \mathrm{CH}_{3 \mathrm{Mes}}-p\right), 2.53\left(\mathrm{~s}, 12 \mathrm{H}, \mathrm{CH}_{3 \mathrm{Mes}}-\mathrm{o}\right)$, 4.43 (br.d, $\left.{ }^{2} J_{\mathrm{HH}}=15.0 \mathrm{~Hz}, 4 \mathrm{H}, \mathrm{P}-\mathrm{CH}_{2}-\mathrm{N}\right), 4.51\left(\mathrm{dd},{ }^{2} J_{\mathrm{HH}}=15.0 \mathrm{~Hz},{ }^{2} J_{\mathrm{PH}}=3.2 \mathrm{~Hz}, 4 \mathrm{H}, \mathrm{P}-\mathrm{CH}_{2}-\mathrm{N}\right), 6.27$ $\left(\mathrm{d},{ }^{3} J_{\mathrm{HH}}=8.4 \mathrm{~Hz}, 4 \mathrm{H}, \mathrm{NC}_{6} \mathrm{H}_{4} \mathrm{CH}_{3}-0\right), 6.92\left(\mathrm{~d},{ }^{3} J_{\mathrm{HH}}=8.4 \mathrm{~Hz}, 4 \mathrm{H}, \mathrm{NC}_{6} \mathrm{H}_{4} \mathrm{CH}_{3}-m\right), 6.96\left(\mathrm{~s}, 4 \mathrm{H}, \mathrm{H}_{\mathrm{Mes}}\right)$. ${ }^{31} \mathrm{P}\left\{{ }^{1} \mathrm{H}\right\}$ NMR $\left(\mathrm{CDCl}_{3}\right): \delta_{\mathrm{P}}-44.41$ (s). Anal. Calc. for $\mathrm{C}_{36} \mathrm{H}_{44} \mathrm{P}_{2} \mathrm{~N}_{2}$ (566.70): C 76.30, H 7.83, N 4.94, $\mathrm{P}$ 10.93\%. Found: C 76.18, H 7.92, N 4.75, P 10.78\%.

Bis(3,7-Diphenyl-1,5-di(p-methoxyphenyl)-1,5-diaza-3,7-diphosphacyclooctane)-bis(acetonitrile)iron(II)] tetrafluoroborate (6). [ $\left.\mathrm{Fe}\left(\mathrm{CH}_{3} \mathrm{CN}\right)_{6}\right]\left(\mathrm{BF}_{4}\right)_{2}(0.088 \mathrm{~g}, 0.19 \mathrm{mmol})$ in dry acetonitrile $(4 \mathrm{~mL})$ was added to $1(0.200 \mathrm{~g}, 0.38 \mathrm{mmol})$ in dry chlorophorm $(4 \mathrm{~mL})$. The reaction mixture was stirred at room temperature for $12 \mathrm{~h}$. The ligand was completely dissolved, and the reaction mixture turned dark-red. The reaction mixture was concentrated to ca. $3 \mathrm{~mL}$ under reduced pressure, the precipitate was filtered off, washed with diethyl ether, and dried for $3 \mathrm{~h}$ at $2 \cdot 10^{-2}$ torr to give complex 6 as a brown powder $(0.112 \mathrm{~g}, 43 \%)$. Decomposed at $160{ }^{\circ} \mathrm{C} .{ }^{1} \mathrm{H}-\mathrm{NMR}\left(\mathrm{CD}_{3} \mathrm{CN}\right): \delta 1.96\left(\mathrm{~s}, 6 \mathrm{H}, \mathrm{CH}_{3} \mathrm{CN}\right), 3.62(\mathrm{~s}, 6 \mathrm{H}$, $\left.-\mathrm{OCH}_{3}\right), 3.74\left(\mathrm{~d},{ }^{2} J_{\mathrm{HH}}=6.5 \mathrm{~Hz}, 4 \mathrm{H}, \mathrm{P}-\mathrm{CH}_{2}-\mathrm{N}\right), 3.79\left(\mathrm{~m}, 4 \mathrm{H}, \mathrm{P}-\mathrm{CH}_{2}-\mathrm{N}\right), 3.88\left(\mathrm{~s}, 6 \mathrm{H},-\mathrm{OCH}_{3}\right), 4.06-4.11$ $\left(\mathrm{m}, 4 \mathrm{H}, \mathrm{P}-\mathrm{CH}_{2}-\mathrm{N}\right), 4.32-4.35\left(\mathrm{~m}, 4 \mathrm{H}, \mathrm{P}-\mathrm{CH}_{2}-\mathrm{N}\right), 6.68\left(\mathrm{~d},{ }^{3} \mathrm{~J}_{\mathrm{HH}}=9 \mathrm{~Hz}, 4 \mathrm{H}, \mathrm{N}-\mathrm{C}_{6} \mathrm{H}_{4} \mathrm{OCH}_{3}-\mathrm{o}\right), 6.78$ $\left(\mathrm{d},{ }^{3} J_{\mathrm{HH}}=8 \mathrm{~Hz}, 4 \mathrm{H}, \mathrm{N}-\mathrm{C}_{6} \mathrm{H}_{4} \mathrm{OCH}_{3}-0\right), 6.80\left(\mathrm{~d},{ }^{3} J_{\mathrm{HH}}=8 \mathrm{~Hz}, 4 \mathrm{H}, \mathrm{N}_{-} \mathrm{C}_{6} \mathrm{H}_{4} \mathrm{OCH}_{3}-m\right), 6.97\left(\mathrm{~d},{ }^{3} J_{\mathrm{HH}}=9 \mathrm{~Hz}\right.$, $\left.4 \mathrm{H}, \mathrm{N}-\mathrm{C}_{6} \mathrm{H}_{4} \mathrm{OCH}_{3}-m\right), 7.51-7.55\left(\mathrm{~m}, 4 \mathrm{H}, \mathrm{H}_{\mathrm{ar}}\right), 7.70$ (br s, $\left.7 \mathrm{H}, H_{\mathrm{ar}}\right), 7.82\left(\mathrm{br} \mathrm{s}, 9 \mathrm{H}, H_{\mathrm{ar}}\right) .{ }^{31} \mathrm{P}\left\{{ }^{1} \mathrm{H}\right\} \mathrm{NMR}$ $\left(\mathrm{CD}_{3} \mathrm{CN}\right): \delta_{\mathrm{P}} 30.52-31.46(\mathrm{~m}), 34.23-35.20(\mathrm{~m})$. ESI MS: $\mathrm{m} / z 542\left[6-2 \mathrm{BF}_{4}-2 \mathrm{CH}_{3} \mathrm{CN}\right]^{2+}, 1103\left[6-2 \mathrm{BF}_{4}-2\right.$ $\left.\mathrm{CH}_{3} \mathrm{CN}+\mathrm{H}_{2} \mathrm{O}\right]^{+}$. Anal. Calc. for $\mathrm{C}_{64} \mathrm{H}_{70} \mathrm{P}_{4} \mathrm{~N}_{6} \mathrm{O}_{4} \mathrm{FeB}_{2} \mathrm{~F}_{8}$ (1340.63): C 57.34, H 5.26, N 6.27, P 9.24\%. Found: C 57.03, H 5.41, N 6.49, P 9.08\%.

[Bis(3,7-Dibenzyl-1,5-diphenyl-1,5-diaza-3,7-diphosphacyclooctane)-bis(acetonitrile)iron(II)] tetrafluoroborate (7). $\left[\mathrm{Fe}\left(\mathrm{CH}_{3} \mathrm{CN}\right)_{6}\right]\left(\mathrm{BF}_{4}\right)_{2}(0.0953 \mathrm{~g}, 0.215 \mathrm{mmol})$ in dry acetonitrile $(6 \mathrm{~mL})$ was added to a suspension of $2(0.2081 \mathrm{~g} 0.43 \mathrm{mmol})$ in dry acetonitrile $(70 \mathrm{~mL})$ at $70^{\circ} \mathrm{C}$. The reaction mixture was stirred at $70{ }^{\circ} \mathrm{C}$ for $3.5 \mathrm{~h}$ and then at room temperature for $12 \mathrm{~h}$. The ligand was completely dissolved, and the reaction mixture turned yellow-orange. The reaction mixture was concentrated to ca. $25 \mathrm{~mL}$ under reduced pressure, and the residue was crystallized at $-15^{\circ} \mathrm{C}$ for $24 \mathrm{~h}$. The precipitate was filtered off, washed twice with cold acetonitrile and then with diethyl ether, and dried for $3 \mathrm{~h}$ at $2 \cdot 10^{-2}$ torr to give complex 7 as yellow crystals $(0.110 \mathrm{~g}, 40 \%)$. M.p. $>200{ }^{\circ} \mathrm{C}$ (decomp.)

${ }^{1} \mathrm{H}-\mathrm{NMR}\left(\mathrm{CD}_{3} \mathrm{CN}\right): \delta 1.96\left(\mathrm{~s}, 6 \mathrm{H}, \mathrm{CH}_{3} \mathrm{CN}\right), 2.39\left(\mathrm{~d},{ }^{2} J_{\mathrm{HH}}=12.8 \mathrm{~Hz}, 2 \mathrm{H}, \mathrm{P}-\mathrm{CH}_{2}-\mathrm{Ph}\right), 2.78$ $\left(\mathrm{d},{ }^{2} J_{\mathrm{HH}}=13.6 \mathrm{~Hz}, 2 \mathrm{H}, \mathrm{P}-\mathrm{CH}_{2}-\mathrm{Ph}\right), 3.32-3.68\left(\mathrm{~m}, 10 \mathrm{H}, \mathrm{P}-\mathrm{CH}_{2}-\mathrm{Ph}+\mathrm{P}-\mathrm{CH}_{2}-\mathrm{N}\right), 3.96-4.24(\mathrm{~m}, 8 \mathrm{H}$, P-CH $-\mathrm{N}), 4.34-4.44\left(\mathrm{~m}, 2 \mathrm{H}, \mathrm{P}-\mathrm{CH}_{2}-\mathrm{N}\right), 6.50\left(\mathrm{~d},{ }^{3} \mathrm{~J}_{\mathrm{HH}}=8.0 \mathrm{~Hz}, 4 \mathrm{H}, \mathrm{N}-\mathrm{C}_{6} \mathrm{H}_{5}-\mathrm{o}\right), 6.56\left(\mathrm{br} \mathrm{d},{ }^{3} J_{\mathrm{HH}}=7.2 \mathrm{~Hz}\right.$,

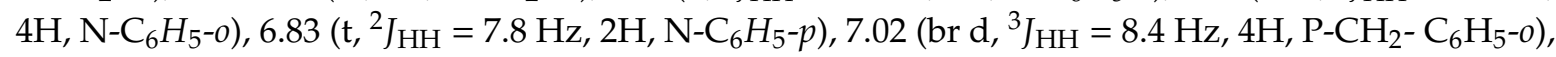
7.07-7.15 (m, 6H, $\left.H_{\mathrm{ar}}\right), 7.19-7.28\left(\mathrm{~m}, 6 \mathrm{H}, H_{\mathrm{ar}}\right), 7.42-7.49\left(\mathrm{~m}, 6 \mathrm{H}, H_{\mathrm{ar}}\right), 7.54-7.64\left(\mathrm{~m}, 8 \mathrm{H}, H_{\mathrm{ar}}\right) .{ }^{31} \mathrm{P}\left\{{ }^{1} \mathrm{H}\right\}$ NMR $\left(\mathrm{CD}_{3} \mathrm{CN}\right): \delta_{\mathrm{P}} 31.44(\mathrm{~m}), 35.57(\mathrm{~m})$. MALDI MS: $m / z: 1019.7\left[7-2 \mathrm{BF}_{4}-2 \mathrm{CH}_{3} \mathrm{CN}\right]^{+}, 1050.7$ [7-2BF $\left.4-2 \mathrm{CH}_{3} \mathrm{CN}-\mathrm{H}+2 \mathrm{O}\right]^{+}$. IR (Nujol, $\left.v, \mathrm{~cm}^{-1}\right): 1060$ vs. br. $\left(\mathrm{BF}_{4}\right)$. Anal. Calc. for $\mathrm{C}_{64} \mathrm{H}_{70} \mathrm{P}_{4} \mathrm{~N}_{6} \mathrm{FeB}_{2} \mathrm{~F}_{8}$ (1276.63): C 60.21, H 5.53, N 6.58, P 9.70\%. Found: C 60.06, H 5.64, N 6.71, P 9.56\%.

[Bis(3,7-Dibenzyl-1,5-di(1'-(R)-phenylethyl)-1,5-diaza-3,7-diphosphacyclooctane)-bis(acetonitrile)iron(II)] tetrafluoroborate $(8)$. $\left[\mathrm{Fe}\left(\mathrm{CH}_{3} \mathrm{CN}\right)_{6}\right]\left(\mathrm{BF}_{4}\right)_{2}(0.0371 \mathrm{~g}, 0.085 \mathrm{mmol})$ in dry acetonitrile $(1 \mathrm{~mL})$ was added to a solution of $3(0.0904 \mathrm{~g}, 0.17 \mathrm{mmol})$ in $10 \mathrm{~mL}$ dry acetonitrile. The reaction mixture was stirred at room temperature for $12 \mathrm{~h}$ and turned yellow-brown. The reaction mixture was concentrated to ca. $3 \mathrm{~mL}$ under reduced pressure, and the diethyl ether $(5 \mathrm{~mL})$ was added to precipitate the product. The precipitate was filtered off, washed twice with diethyl ether, and dried for $3 \mathrm{~h}$ at $2 \cdot 10^{-2}$ torr to give complex 8 as a yellow powder $(0.131 \mathrm{~g}, 56 \%)$. Decomposed at $140{ }^{\circ} \mathrm{C}$. 
${ }^{1} \mathrm{H}-\mathrm{NMR}\left(\mathrm{CD}_{3} \mathrm{CN}\right): \delta 0.55\left(\mathrm{~d},{ }^{3} J_{\mathrm{HH}}=6.6 \mathrm{~Hz}, 6 \mathrm{H}, \mathrm{CH}(\mathrm{Me}) \mathrm{Ph}\right), 1.74\left(\mathrm{~d},{ }^{3} J_{\mathrm{HH}}=7.2 \mathrm{~Hz}, 6 \mathrm{H}\right.$, $\mathrm{CH}(\mathrm{Me}) \mathrm{Ph}$ ), 1.96 (s, 6H, CH $\mathrm{CHN}_{3}$, 2.14-2.29 (m, 8H, P-CH $\left.-\mathrm{Ph}\right), 2.81-2.85$ (m, 2H, P-CH $\left.-\mathrm{N}\right), 2.96-3.02$ $\left(\mathrm{m}, 2 \mathrm{H}, \mathrm{P}-\mathrm{CH}_{2}-\mathrm{N}\right), 3.09-3.19\left(\mathrm{~m}, 4 \mathrm{H}, \mathrm{P}-\mathrm{CH}_{2}-\mathrm{N}\right), 3.24-3.32\left(\mathrm{~m}, 4 \mathrm{H}, \mathrm{P}-\mathrm{CH}_{2}-\mathrm{N}+\mathrm{CH}(\mathrm{Me}) \mathrm{Ph}\right), 3.62$ (d.m, $\left.{ }^{2} J_{\mathrm{HH}}=15.0 \mathrm{~Hz}, 2 \mathrm{H}, \mathrm{P}-\mathrm{CH}_{2}-\mathrm{N}\right), 3.74$ (br.d, $\left.{ }^{2} J_{\mathrm{HH}}=15.0 \mathrm{~Hz}, 2 \mathrm{H}, \mathrm{P}-\mathrm{CH}_{2}-\mathrm{N}\right), 3.88\left(\mathrm{~m}, 2 \mathrm{H}, \mathrm{P}-\mathrm{CH}_{2}-\mathrm{N}\right), 4.18$ $\left(\mathrm{q},{ }^{3} J_{\mathrm{HH}}=7.2 \mathrm{~Hz}, 2 \mathrm{H}, \mathrm{CH}(\mathrm{Me}) \mathrm{Ph}\right), 6.69\left(\mathrm{~m}, 4 \mathrm{H}, H_{\mathrm{ar}}\right), 7.07-7.45\left(\mathrm{~m}, 36 \mathrm{H}, H_{\mathrm{ar}}\right) .{ }^{31} \mathrm{P}\left\{{ }^{1} \mathrm{H}\right\} \mathrm{NMR}\left(\mathrm{CD}_{3} \mathrm{CN}\right)$ : $\delta_{\mathrm{P}} 25.61(\mathrm{~m}), 34.19(\mathrm{~m}) . \mathrm{ESI}_{\text {pos }}$ MS: $\mathrm{m} / z 1208$ [8-2 $\mathrm{BF}_{4}-\mathrm{CH}_{3} \mathrm{CN}+\mathrm{F}+\mathrm{O}^{+}, 1192\left[8-2 \mathrm{BF}_{4}-\mathrm{CH}_{3} \mathrm{CN}+\mathrm{F}\right]^{+}$. IR (Nujol, v, $\mathrm{cm}^{-1}$ ): 1060 vs. br. $\left(\mathrm{BF}_{4}\right.$ ). Anal. Calc. for $\mathrm{C}_{72} \mathrm{H}_{86} \mathrm{~N}_{6} \mathrm{P}_{4} \mathrm{FeB}_{2} \mathrm{~F}_{8}$ [1388.84]: C 62.27, $\mathrm{H}$ 6.24, $\mathrm{N}$ 6.05, P 8.92\%. Found: C 61.96, H 6.40, N 6.36, P 8.74\%.

[Bis(3,7-Di(pyridine-2'-yl)-1,5-di(p-tolyl)-1,5-diaza-3,7-diphosphacyclooctane)-bis(acetonitrile)iron(II)] tetrafluoroborate (9). 9 as an orange powder was obtained like 8 from $4(0.0985 \mathrm{~g}, 0.203 \mathrm{mmol})$ and $\left[\mathrm{Fe}\left(\mathrm{CH}_{3} \mathrm{CN}\right)_{6}\right]\left(\mathrm{BF}_{4}\right)_{2}(0.0447 \mathrm{~g}, 0.101 \mathrm{mmol})$, except that 4 was used as a suspension. The yield of 9 was $0.079 \mathrm{~g}(61 \%)$. Decomposed at $160{ }^{\circ} \mathrm{C} .{ }^{1} \mathrm{H}-\mathrm{NMR}\left(\mathrm{CD}_{3} \mathrm{CN}\right): \delta 1.96\left(\mathrm{~s}, 6 \mathrm{H}, \mathrm{CH}_{3} \mathrm{CN}\right), 2.11(\mathrm{~s}, 6 \mathrm{H}$, $\left.\mathrm{NC}_{6} \mathrm{H}_{4} \mathrm{CH}_{3}\right), 2.32\left(\mathrm{~s}, 6 \mathrm{H}, \mathrm{NC}_{6} \mathrm{H}_{4} \mathrm{CH}_{3}\right), 2.90-2.99\left(\mathrm{~m}, 2 \mathrm{H}, \mathrm{P}-\mathrm{CH}_{2}-\mathrm{N}\right), 3.28$ (br.d, ${ }^{2} J_{\mathrm{HH}}=12.8 \mathrm{~Hz}, 2 \mathrm{H}$, P-CH ${ }_{2}-\mathrm{N}$ ), 3.34 (br.d, ${ }^{2} J_{\mathrm{HH}}=14.2 \mathrm{~Hz}, 2 \mathrm{H}, \mathrm{P}-\mathrm{CH}_{2}-\mathrm{N}$ ), 3.41 (br.d, ${ }^{2} J_{\mathrm{HH}}=11.6 \mathrm{~Hz}, 2 \mathrm{H}, \mathrm{P}-\mathrm{CH}_{2}-\mathrm{N}$ ), 3.73-3.83 (m, 2H, P-CH $\left.{ }_{2}-\mathrm{N}\right), 4.13$ (br.d, $\left.{ }^{2} \mathrm{~J}_{\mathrm{HH}}=14.2 \mathrm{~Hz}, 2 \mathrm{H}, \mathrm{P}-\mathrm{CH}_{2}-\mathrm{N}\right), 4.24-4.33\left(\mathrm{~m}, 2 \mathrm{H}, \mathrm{P}-\mathrm{CH}_{2}-\mathrm{N}\right)$, $4.38-4.48\left(\mathrm{~m}, 2 \mathrm{H}, \mathrm{P}-\mathrm{CH}_{2}-\mathrm{N}\right), 6.52\left(\mathrm{~d},{ }^{3} J_{\mathrm{HH}}=8.6 \mathrm{~Hz}, 4 \mathrm{H}, \mathrm{NC}_{6} \mathrm{H}_{4} \mathrm{CH}_{3}-\mathrm{o}\right), 6.71\left(\mathrm{~d},{ }^{3} J_{\mathrm{HH}}=8.4 \mathrm{~Hz}, 4 \mathrm{H}\right.$, $\left.\mathrm{NC}_{6} \mathrm{H}_{4} \mathrm{CH}_{3}-0\right), 6.91\left(\mathrm{~d},{ }^{3} \mathrm{~J}_{\mathrm{HH}}=8.6 \mathrm{~Hz}, 4 \mathrm{H}, \mathrm{NC}_{6} \mathrm{H}_{4} \mathrm{CH}_{3}-m\right), 6.95\left(\mathrm{~m}, 2 \mathrm{H}, \mathrm{H}^{4} \mathrm{pyr}\right), 7.11\left(\mathrm{~d},{ }^{3} J_{\mathrm{HH}}=8.4 \mathrm{~Hz}\right.$, $\left.4 \mathrm{H}, \mathrm{NC}_{6} \mathrm{H}_{4} \mathrm{CH}_{3}-m\right), 7.36\left(\mathrm{~m}, 2 \mathrm{H}, \mathrm{H}^{4}{ }_{\text {pyr }}\right), 7.51\left(\mathrm{~m}, 2 \mathrm{H}, \mathrm{H}^{5}\right.$ pyr $), 7.70\left(\mathrm{~m}, 2 \mathrm{H}, \mathrm{H}^{5}\right.$ pyr $), 7.95$ (br.d, ${ }^{3} J_{\mathrm{HH}}=8.0$ $\mathrm{Hz}, 2 \mathrm{H}, H^{6}$ pyr $), 8.13$ (br.d, ${ }^{3} J_{\mathrm{HH}}=4.4 \mathrm{~Hz}, 2 \mathrm{H}, H^{3}$ pyr $), 8.16\left(\mathrm{~m}, 2 \mathrm{H}, H^{6}{ }_{\mathrm{pyr}}\right), 9.03$ (br.d, ${ }^{3} J_{\mathrm{HH}}=3.6 \mathrm{~Hz}, 2 \mathrm{H}$, $H^{3}$ pyr $) .{ }^{31} \mathrm{P}\left\{{ }^{1} \mathrm{H}\right\}$ NMR $\left(\mathrm{CD}_{3} \mathrm{CN}\right): \delta_{\mathrm{P}} 34.69(\mathrm{~m}), 41.13(\mathrm{~m}) . \mathrm{ESI}_{\text {pos }} \mathrm{MS}: \mathrm{m} / z$ 512.4 $\left[9-2 \mathrm{BF}_{4}-2 \mathrm{CH}_{3} \mathrm{CN}\right]^{2+}$, 1059.6 [9-2 $\mathrm{BF}_{4}-2 \mathrm{CH}_{3} \mathrm{CN}+\mathrm{F}+\mathrm{O}^{+}$. IR $\left(\mathrm{Nujol}, v, \mathrm{~cm}^{-1}\right)$ : 1060 vs. br. $\left(\mathrm{BF}_{4}\right)$. Anal. Calc. for $\mathrm{C}_{60} \mathrm{H}_{66} \mathrm{~N}_{10} \mathrm{P}_{4} \mathrm{FeB}_{2} \mathrm{~F}_{8}$ [1280.58]: C 56.27, H 5.19, $\mathrm{N}$ 10.94, P 9.67\%. Found: C 56.09, H 5.31, N 11.17, $\mathrm{P} 9.49 \%$.

[(3,7-Dimesityl-1,5-di(p-tolyl)-1,5-diaza-3,7-diphosphacyclooctane)tetrakis-(acetonitrile)iron(II)]

tetrafluoroborate (10). $\left[\mathrm{Fe}\left(\mathrm{CH}_{3} \mathrm{CN}\right)_{6}\right]\left(\mathrm{BF}_{4}\right)_{2}(0.240 \mathrm{~g}, 0.53 \mathrm{mmol})$ in dry acetonitrile $(2 \mathrm{~mL})$ was added to a solution of $5(0.300 \mathrm{~g}, 0.53 \mathrm{mmol})$ in dry acetonitrile $(6 \mathrm{~mL})$. The reaction mixture was stirred at room temperature for $48 \mathrm{~h}$. The ligand was completely dissolved, and the reaction mixture turned brown. The reaction mixture was concentrated to ca. $3 \mathrm{~mL}$ under reduced pressure, and the residue was crystallized at $-15^{\circ} \mathrm{C}$ for $12 \mathrm{~h}$. The precipitate was filtered off, washed with diethyl ether, and dried for $3 \mathrm{~h}$ at $2 \cdot 10^{-2}$ torr to give complex 10 as a dark-red powder $(0.116 \mathrm{~g}, 28 \%)$. Decomposed at $130{ }^{\circ} \mathrm{C} .{ }^{1} \mathrm{H}-\mathrm{NMR}\left(\mathrm{CD}_{3} \mathrm{CN}\right): \delta 2.18\left(\mathrm{~s}, 6 \mathrm{H}, \mathrm{NC}_{6} \mathrm{H}_{4} \mathrm{CH}_{3}\right), 2.38\left(\mathrm{~s}, 6 \mathrm{H}, \mathrm{CH}_{3 \mathrm{Mes}}-\mathrm{p}\right), 2.44\left(\mathrm{~s}, 12 \mathrm{H}, \mathrm{CH}_{3 \mathrm{Mes}}-\mathrm{o}\right)$, 4.77-4.82 (m, 4H, P-CH $-\mathrm{N}), 4.93-4.97\left(\mathrm{~m}, 4 \mathrm{H}, \mathrm{P}-\mathrm{CH}_{2}-\mathrm{N}\right), 6.54\left(\mathrm{br} \mathrm{s}, 4 \mathrm{H}, \mathrm{NC}_{6} \mathrm{H}_{4} \mathrm{CH}_{3}-\mathrm{o}\right), 6.99$ (br.d, ${ }^{3} J_{\mathrm{HH}}$ $\left.=6 \mathrm{~Hz}, 4 \mathrm{H}, \mathrm{NC}_{6} \mathrm{H}_{4} \mathrm{CH}_{3}-m\right), 7.17\left(\mathrm{~s}, 4 \mathrm{H}, H_{\mathrm{Mes}}\right) .{ }^{31} \mathrm{P}\left\{{ }^{1} \mathrm{H}\right\} \mathrm{NMR}\left(\mathrm{CD}_{3} \mathrm{CN}\right): \delta_{\mathrm{P}} 55.56$. MALDI MS: $m / z 621$

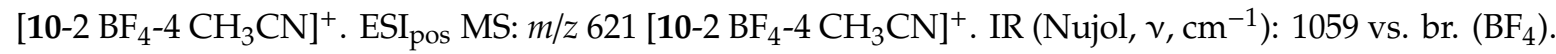
Anal. Calc. for $\mathrm{C}_{44} \mathrm{H}_{56} \mathrm{~N}_{6} \mathrm{P}_{2} \mathrm{FeB}_{2} \mathrm{~F}_{8}$ [960.36]: C 55.03, H 5.88, N 8.75, P 6.45\%. Found: C 54.87, H 6.01, N 8.97, P $6.28 \%$.

[Bis(3,7-Dibenzyl-1,5-di(1'-(R)-phenylethyl)-1,5-diaza-3,7-diphosphacyclooctane)- tetrafluoroboratoiron(II)] tetrafluoroborate $(\mathbf{1 1 b})$. [ $\left.\mathrm{Fe}\left(\mathrm{H}_{2} \mathrm{O}\right)_{6}\right]\left(\mathrm{BF}_{4}\right)_{2}(0.0314 \mathrm{~g}, 0.095 \mathrm{mmol})$ was added to a solution of $3(0.100 \mathrm{~g}$, $0.19 \mathrm{mmol})$ in dry acetone $(10 \mathrm{~mL})$. The reaction mixture was stirred at room temperature for $12 \mathrm{~h}$ and turned dark-red. In ${ }^{31} \mathrm{P}-\mathrm{NMR}$ spectrum, two pairs of doublets were observed at 38.21 and 31.03 ppm $\left({ }^{2} J_{\mathrm{PP}} \approx{ }^{2} J_{\mathrm{PP}} \approx 70.7 \mathrm{~Hz}\right)(\mathbf{1 1 a}), 37.30$ and $29.94 \mathrm{ppm}\left({ }^{2} J_{\mathrm{PP}} \approx{ }^{2} J_{\mathrm{PP}} \approx 71.8 \mathrm{~Hz}\right)(\mathbf{1 1 b})$ with a ratio of intensities of 1.4:1. The reaction mixture was concentrated to ca. $2 \mathrm{~mL}$ under reduced pressure, and the residue was crystallized at $-15^{\circ} \mathrm{C}$ for $12 \mathrm{~h}$. The precipitate was filtered off, washed with cold acetone, and dried for $3 \mathrm{~h}$ at $2 \cdot 10^{-2}$ torr to give complex $11 \mathrm{~b}$ as dark-red small crystals $(0.054$ g, 44\%). M.p. > $140{ }^{\circ} \mathrm{C}$ (decomp.) ${ }^{1} \mathrm{H}-\mathrm{NMR}$ (acetone- $\left.\mathrm{d}_{6}\right): \delta 1.10\left(\mathrm{~d},{ }^{3} \mathrm{~J}_{\mathrm{HH}}=6.8 \mathrm{~Hz}, 6 \mathrm{H}, \mathrm{CH}(\mathrm{Me}) \mathrm{Ph}\right)$, $1.58\left(\mathrm{~d},{ }^{3} J_{\mathrm{HH}}=6.8 \mathrm{~Hz}, 6 \mathrm{H}, \mathrm{CH}(\mathrm{Me}) \mathrm{Ph}\right), 1.84\left(\mathrm{br} . \mathrm{d},{ }^{2} J_{\mathrm{HH}}=14.2 \mathrm{~Hz}, 2 \mathrm{H}, \mathrm{P}-\mathrm{CH}_{2}-\mathrm{Ph}\right), 1.94-1.99(\mathrm{~m}, 2 \mathrm{H}$, P-CH $-\mathrm{Ph}), 2.44-2.52\left(\mathrm{~m}, 2 \mathrm{H}, \mathrm{P}-\mathrm{CH}_{2}-\mathrm{N}\right), 2.65\left(\mathrm{br} \mathrm{d}, 2 \mathrm{H},{ }^{2} \mathrm{~J}_{\mathrm{HH}}=14.2 \mathrm{~Hz}, \mathrm{P}-\mathrm{CH}_{2}-\mathrm{Ph}\right), 2.91-2.98(\mathrm{~m}, 2 \mathrm{H}$, P-CH $-\mathrm{N}), 3.04-3.11\left(\mathrm{~m}, 4 \mathrm{H}, \mathrm{P}-\mathrm{CH}_{2}-\mathrm{N}\right), 3.22\left(\mathrm{br} \mathrm{d}^{2}{ }^{2} \mathrm{HH}=13.2 \mathrm{~Hz}, 2 \mathrm{H}, \mathrm{P}_{\mathrm{H}} \mathrm{CH}_{2}-\mathrm{N}\right), 3.54-3.63(\mathrm{~m}, 2 \mathrm{H}$, 
P-CH $-\mathrm{N}), 3.68\left(\mathrm{q}^{3}{ }^{3} \mathrm{H}_{\mathrm{HH}}=6.8 \mathrm{~Hz}, 2 \mathrm{H}, \mathrm{CH}(\mathrm{Me}) \mathrm{Ph}\right), 3.84-3.94\left(\mathrm{~m}, 4 \mathrm{H}, \mathrm{P}-\mathrm{CH}_{2}-\mathrm{N}\right), 4.01\left(\mathrm{~m}, 2 \mathrm{H}, \mathrm{P}-\mathrm{CH}_{2}-\mathrm{N}\right)$, $4.14\left(\mathrm{q},{ }^{3} J_{\mathrm{HH}}=6.8 \mathrm{~Hz}, 2 \mathrm{H}, \mathrm{CH}(\mathrm{Me}) \mathrm{Ph}\right), 6.74-6.79\left(\mathrm{~m}, 4 \mathrm{H}, H_{\mathrm{ar}}\right), 6.85-6.90\left(\mathrm{~m}, 4 \mathrm{H}, H_{\mathrm{ar}}\right), 7.10-7.55(\mathrm{~m}$, $\left.32 \mathrm{H}, H_{\mathrm{ar}}\right) \cdot{ }^{31} \mathrm{P}\left\{{ }^{1} \mathrm{H}\right\} \mathrm{NMR}\left(\right.$ acetone- $\left.\mathrm{d}_{6}\right): \delta_{\mathrm{P}} 37.30\left(\mathrm{dd},{ }^{2} J_{\mathrm{PP}}={ }^{2} J_{\mathrm{PP}}=71.8 \mathrm{~Hz}\right), 29.94\left(\mathrm{dd},{ }^{2} J_{\mathrm{PP}}={ }^{2} J_{\mathrm{PP}}=71.8\right.$ Hz). MALDI MS: $m / z 1132\left[11 \mathrm{~b}-2 \mathrm{BF}_{4}\right]^{+}, 1162\left[11 \mathrm{~b}-\mathrm{BF}_{4}-3 \mathrm{~F}\right]^{+}$. IR (Nujol, $\left.v, \mathrm{~cm}^{-1}\right)$ : 1057 vs. br. $\left(\mathrm{BF}_{4}\right)$. Anal. Calc for $\mathrm{C}_{68} \mathrm{H}_{80} \mathrm{~N}_{4} \mathrm{P}_{4} \mathrm{FeB}_{2} \mathrm{~F}_{8}$ [1306.74]: C 62.50, H 6.17, N 4.29, P 9.48\%. Found: C 62.39, H 6.31, N 4.18, P 9.23\%.

[(Cyclopentadienyl)carbonyl(3,7-dibenzyl-1,5-di(1'-(R)-phenylethyl)-1,5-diaza-3,7-diphosphacyclooctane)iron(II)] tetrafluoroborate (12). A solution of $3(0.1036 \mathrm{~g}, 0.192 \mathrm{mmol})$ in dry toluene $(10 \mathrm{~mL})$ was added to solid $\left[\mathrm{CpFe}(\mathrm{CO})_{2}(\mathrm{THF})\right] \mathrm{BF}_{4}(0.0646 \mathrm{~g}, 0.192 \mathrm{mmol})$. The reaction mixture was stirred at room temperature for $24 \mathrm{~h}$ and turned yellow-orange. The small amount of a sticky dark resin was removed by the centrifugation, the volatiles were removed from the filtrate under reduced pressure, and the residue was crystallized from diethyl ether. The precipitate was filtered off, washed twice with diethyl ether, and dried for $3 \mathrm{~h}$ at $2 \cdot 10^{-2}$ torr to give complex 12 as a yellow powder $(0.122 \mathrm{~g}, 82 \%)$. M.p. $177-180^{\circ} \mathrm{C}$ (decomp.) ${ }^{1} \mathrm{H}-\mathrm{NMR}$ (acetone- $\left.\mathrm{d}_{6}\right): \delta 1.19\left(\mathrm{~d},{ }^{3} \mathrm{~J}_{\mathrm{HH}}=7.2 \mathrm{~Hz}, 3 \mathrm{H}, \mathrm{CH}(\mathrm{Me}) \mathrm{Ph}\right), 1.44\left(\mathrm{~d},{ }^{3} J_{\mathrm{HH}}=6.8 \mathrm{~Hz}, 3 \mathrm{H}\right.$, $\mathrm{CH}(\mathrm{Me}) \mathrm{Ph}), 2.58\left(\mathrm{~d},{ }^{2} \mathrm{~J}_{\mathrm{HH}}=13.5 \mathrm{~Hz}, 1 \mathrm{H}, \mathrm{P}-\mathrm{CH}_{2}-\mathrm{Ph}\right), 2.61\left(\mathrm{~d},{ }^{2} J_{\mathrm{HH}}=12.8 \mathrm{~Hz}, 1 \mathrm{H}, \mathrm{P}-\mathrm{CH}_{2}-\mathrm{Ph}\right), 2.73-2.89$ $\left(\mathrm{m}, 4 \mathrm{H}, \mathrm{P}-\mathrm{CH}_{2}-\mathrm{N}\right.$, partially overlapped with the signal of $\mathrm{H}_{2} \mathrm{O}$ in $\left.\left(\mathrm{CD}_{3}\right)_{2} \mathrm{C}(\mathrm{O})\right), 3.12\left(\mathrm{~d},{ }^{2} J_{\mathrm{HH}}=13.5 \mathrm{~Hz}\right.$, $\left.1 \mathrm{H}, \mathrm{P}-\mathrm{CH}_{2}-\mathrm{Ph}\right), 3.18\left(\mathrm{~d},{ }^{2} J_{\mathrm{HH}}=12.8 \mathrm{~Hz}, 1 \mathrm{H}, \mathrm{P}-\mathrm{CH}_{2}-\mathrm{Ph}\right), 3.53-3.64\left(\mathrm{~m}, 2 \mathrm{H}, \mathrm{P}-\mathrm{CH}_{2}-\mathrm{N}\right), 3.66-3.78$ $\left(\mathrm{m}, 3 \mathrm{H}, \mathrm{P}-\mathrm{CH}_{2}-\mathrm{N}+\mathrm{CH}(\mathrm{Me}) \mathrm{Ph}\right), 4.05\left(\mathrm{q},{ }^{3} \mathrm{~J}_{\mathrm{HH}}=7.2 \mathrm{~Hz}, 1 \mathrm{H}, \mathrm{CH}(\mathrm{Me}) \mathrm{Ph}\right), 5.18\left(\mathrm{~s}, 5 \mathrm{H}, \mathrm{C}_{5} \mathrm{H}_{5}\right), 7.01-7.05$ $\left(\mathrm{m}, 2 \mathrm{H}, H_{\mathrm{ar}}\right), 7.15-7.24\left(\mathrm{~m}, 6 \mathrm{H}, H_{\mathrm{ar}}\right), 7.25-7.36\left(\mathrm{~m}, 12 \mathrm{H}, H_{\mathrm{ar}}\right) .{ }^{31} \mathrm{P}\left\{{ }^{1} \mathrm{H}\right\}$ NMR (acetone- $\left.\mathrm{d}_{6}\right): \delta_{\mathrm{P}} 55.55$ $\left(\mathrm{d},{ }^{2} J_{\mathrm{PP}}=116.4 \mathrm{~Hz}\right), 56.27\left(\mathrm{~d},{ }^{2} J_{\mathrm{PP}}=116.4 \mathrm{~Hz}\right) . \mathrm{ESI}_{\mathrm{pos}} \mathrm{MS}: \mathrm{m} / z 687.3\left[12-\mathrm{BF}_{4}\right]^{+}$. IR $\left(\mathrm{KBr}, v_{,} \mathrm{cm}^{-1}\right): 1047$ vs. br. $\left(\mathrm{BF}_{4}\right), 1940 \mathrm{~s}(\mathrm{CO}), 1951 \mathrm{~s}(\mathrm{CO})$. Anal. Calc for $\mathrm{C}_{40} \mathrm{H}_{45} \mathrm{~N}_{2} \mathrm{OP}_{2} \mathrm{FeBF}_{4}$ [744.40]: C 62.04, H 5.86, $\mathrm{N}$ 3.62, P 8.00\%. Found: C 61.91, H 5.97, N 3.58, P 7.68\%.

[(Cyclopentadienyl)carbonyl(3,7-di(pyridine-2'-yl)-1,5-di(p-tolyl)-1,5-diaza-3,7-diphosphacyclooctane)iron(II)] tetrafluoroborate (13). A solution of $4(0.0656 \mathrm{~g}, 0.135 \mathrm{mmol})$ in dry toluene $(5 \mathrm{~mL})$ was added to solid $\left[\mathrm{CpFe}(\mathrm{CO})_{2}(\mathrm{THF}) \mathrm{BF}_{4}(0.0456 \mathrm{~g}, 0.136 \mathrm{mmol})\right.$ in dry toluene $(1 \mathrm{~mL})$. The reaction mixture was stirred at $60-70{ }^{\circ} \mathrm{C}$ temperature for 4 days and turned yellow-orange. The formation of a noticeable amount of a sticky dark resin was observed. The resin was removed by the centrifugation, the volatiles were removed from the filtrate under reduced pressure, and the residue was crystallized from diethyl ether. The precipitate was filtered off, washed twice with diethyl ether, and dried for $3 \mathrm{~h}$ at $2 \cdot 10^{-2}$ torr to give complex 13 as a yellow powder $(0.042 \mathrm{~g}, 9 \%)$. Decomposed at $160{ }^{\circ} \mathrm{C} .{ }^{1} \mathrm{H}-\mathrm{NMR}$ (acetone- $\left.\mathrm{d}_{6}\right): \delta$ $2.24\left(\mathrm{~s}, 3 \mathrm{H}, \mathrm{CH}_{3}\right), 2.28\left(\mathrm{~s}, 3 \mathrm{H}, \mathrm{CH}_{3}\right), 4.04\left(\mathrm{~d},{ }^{2} \mathrm{~J}_{\mathrm{HH}}=13.6 \mathrm{~Hz}, 2 \mathrm{H}, \mathrm{P}-\mathrm{CH}_{2}-\mathrm{N}\right), 4.22\left(\mathrm{dm},{ }^{2} J_{\mathrm{HH}}=13.6 \mathrm{~Hz}\right.$, $\left.{ }^{2} J_{\mathrm{PH}} \approx{ }^{4} J_{\mathrm{HH}} \approx 3.4 \mathrm{~Hz}, 2 \mathrm{H}, \mathrm{P}-\mathrm{CH}_{2}-\mathrm{N}\right), 4.44\left(\mathrm{dm},{ }^{2} J_{\mathrm{HH}}=14.0 \mathrm{~Hz},{ }^{2} J_{\mathrm{PH}} \approx{ }^{4} J_{\mathrm{HH}} \approx 3.4 \mathrm{~Hz}, 2 \mathrm{H}, \mathrm{P}-\mathrm{CH}_{2}-\mathrm{N}\right)$, $4.58\left(\mathrm{~d},{ }^{2} \mathrm{~J}_{\mathrm{HH}}=14.0 \mathrm{~Hz}, 2 \mathrm{H}, \mathrm{P}-\mathrm{CH}_{2}-\mathrm{N}\right), 5.05\left(\mathrm{t},{ }^{3} \mathrm{~J}_{\mathrm{PH}}=1.4 \mathrm{~Hz}, 5 \mathrm{H}, \mathrm{C}_{5} \mathrm{H}_{5}\right), 7.10\left(\mathrm{~d},{ }^{3} J_{\mathrm{HH}}=9.0 \mathrm{~Hz}, 2 \mathrm{H}\right.$, $\left.\mathrm{NC}_{6} \mathrm{H}_{4} \mathrm{CH}_{3}-\mathrm{o}\right), 7.15\left(\mathrm{~d},{ }^{3} J_{\mathrm{HH}}=9.0 \mathrm{~Hz}, 2 \mathrm{H}, \mathrm{NC}_{6} \mathrm{H}_{4} \mathrm{CH}_{3}-m\right), 7.20\left(\mathrm{~d},{ }^{3} J_{\mathrm{HH}}=8.8 \mathrm{~Hz}, 2 \mathrm{H}, \mathrm{NC}_{6} \mathrm{H}_{4} \mathrm{CH}_{3}-\mathrm{o}\right)$, $7.29\left(\mathrm{~d},{ }^{3} J_{\mathrm{HH}}=8.8 \mathrm{~Hz}, 2 \mathrm{H}, \mathrm{NC}_{6} \mathrm{H}_{4} \mathrm{CH}_{3}-m\right), 7.64\left(\mathrm{ddm},{ }^{3} J_{\mathrm{HH}}=7.2 \mathrm{~Hz},{ }^{3} J_{\mathrm{HH}}=4.8 \mathrm{~Hz}, 2 \mathrm{H}, H^{4}\right.$ pyr $)$, 8.06-8.15 (m, 4H, $H_{\text {pyr }}^{5}+H^{6}$ pyr $), 8.91\left(\mathrm{~d},{ }^{3} J_{\mathrm{HH}}=4.8 \mathrm{~Hz}, 2 \mathrm{H}, H^{3}{ }_{\mathrm{pyr}}\right) .{ }^{31} \mathrm{P}\left\{{ }^{1} \mathrm{H}\right\}$ NMR $\left(\right.$ acetone- $\left.\mathrm{d}_{6}\right): \delta_{\mathrm{P}}$

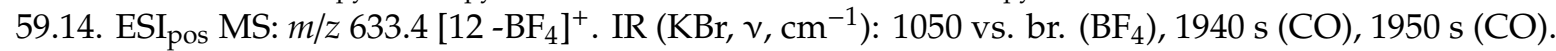
Anal. Calc for $\mathrm{C}_{34} \mathrm{H}_{35} \mathrm{~N}_{4} \mathrm{OP}_{2} \mathrm{FeBF}_{4}$ [720.27]: C 56.70, H 4.90, N 7.78, P 8.60\%. Found: C 56.58, H 5.07, N 4.79 , P $8.43 \%$.

Supplementary Materials: The following are available online. ${ }^{1} \mathrm{H}-\mathrm{NMR},{ }^{31} \mathrm{P}-\mathrm{NMR}$, mass spectra of synthesized compounds, and TG/DSC curve of complex 11b; CIF data for complexes 8 and 11b. Figure S1: ${ }^{31}$ P-NMR spectrum of 3; Figure S2: ${ }^{1} \mathrm{H}-\mathrm{NMR}$ spectrum of 3; Figure S3: ${ }^{31} \mathrm{P}-\mathrm{NMR}$ spectrum of 5; Figure S4: ${ }^{1} \mathrm{H}-\mathrm{NMR}$ spectrum of 5; Figure S5: ${ }^{31} \mathrm{P}-\mathrm{NMR}$ spectrum of 6; Figure S6: ${ }^{1} \mathrm{H}-\mathrm{NMR}$ spectrum of 6; Figure S7: ESI-MS spectrum of 6; Figure S8: ${ }^{31} \mathrm{P}$-NMR spectrum of 7; Figure S9: ${ }^{1} \mathrm{H}-\mathrm{NMR}$ spectrum of 7; Figure S10: MALDI-MS spectrum of 7; Figure S11: ${ }^{31} \mathrm{P}-\mathrm{NMR}$ spectrum of 8; Figure S12: ${ }^{1} \mathrm{H}-\mathrm{NMR}$ spectrum of 8; Figure S13: ${ }^{1} \mathrm{H}-\mathrm{NMR}$ spectrum of 8 (the region of protons of P-CH $2-\mathrm{N}, \mathrm{P}-\mathrm{CH}_{2}-\mathrm{Ph}, \mathrm{CH}(\mathrm{Ph}) \mathrm{Me}$ fragments); Figure S14: ESI-MS spectrum of 8; Figure S15: ${ }^{31} \mathrm{P}-\mathrm{NMR}$ spectrum of 9; Figure S16: ${ }^{1} \mathrm{H}-\mathrm{NMR}$ spectrum of 9; Figure S17: ${ }^{1} \mathrm{H}-\mathrm{NMR}$ spectrum of 9, the region of aromatic protons; Figure S18: ESI-MS spectrum of 9; Figure S19: ${ }^{31} \mathrm{P}-\mathrm{NMR}$ spectrum of 10; Figure S20: ${ }^{1} \mathrm{H}-\mathrm{NMR}$ spectrum of 10; Figure S21: ESI-MS spectrum of 10; Figure S22: ${ }^{31} \mathrm{P}-\mathrm{NMR}$ spectrum of 11b; Figure S23: ${ }^{1} \mathrm{H}-\mathrm{NMR}$ spectrum 
of $\mathbf{1 1 b}$; Figure S24: ${ }^{1} \mathrm{H}-\mathrm{NMR}$ spectrum of $\mathbf{1 1 b}$ (the region of aliphatic protons); Figure S25: MALDI-MS spectrum of 11b; Figure S26: TG/DSK diagram of 11b; Figure S27: ${ }^{31} \mathrm{P}-\mathrm{NMR}$ spectrum of 12; Figure S28: ${ }^{1} \mathrm{H}-\mathrm{NMR}$ spectrum of 12; Figure S29: ${ }^{1} \mathrm{H}-\mathrm{NMR}$ spectrum of 12 (the region of aliphatic protons); Figure S30: ESI-MS spectrum of 12; Figure S31: ${ }^{31} \mathrm{P}-\mathrm{NMR}$ spectrum of 13; Figure S32: ${ }^{1} \mathrm{H}-\mathrm{NMR}$ spectrum of 13; Figure S33: ${ }^{1} \mathrm{H}-\mathrm{NMR}$ spectrum of 13 (the region of aromatic protons); Figure S34: ESI-MS spectrum of 13.

Author Contributions: Conceptualization, E.I.M. and A.A.K.; Funding acquisition, A.A.K.; Investigation, Y.S.S., Y.A.N., A.S.B., I.A.L., I.D.S., and V.V.K.; Methodology, E.I.M., I.A.L., and Y.G.B.; Project administration, A.A.K.; Supervision, A.A.K.; Writing—original draft, A.S.B.; Writing-review and editing, A.A.K. All authors have read and agreed to the published version of the manuscript.

Funding: This research was funded by RFBR, grant number 18-03-00833_a.

Acknowledgments: Authors gratefully acknowledge A.V. Gerasimov and V.V. Gorbachuk from Alexander Butlerov Institute of Chemistry of Kazan Federal University for the TG/DSC analysis, which has been performed in the frame of subsidy allocated to Kazan Federal University for the state assignment in the sphere of scientific activities NO 0671-2020-006. The NMR, IR, mass spectra were obtained, and X-ray diffraction analysis and elemental analysis were performed at the Assigned Spectral-Analytical Center of FRC Kazan Scientific Center of RAS.

Conflicts of Interest: The authors declare no conflict of interest.

\section{References}

1. DuBois, D.L.; Bullock, R.M. Molecular Electrocatalysts for the Oxidation of Hydrogen and the Production of Hydrogen-The Role of Pendant Amines as Proton Relays. Eur. J. Inorg. Chem. 2011, 2011, 1017-1027. [CrossRef]

2. Musina, E.I.; Khrizanforova, V.V.; Strelnik, I.D.; Valitov, M.I.; Spiridonova, Y.S.; Krivolapov, D.B.; Litvinov, I.A.; Kadirov, M.K.; Lönnecke, P.; Hey-Hawkins, E.; et al. New Functional Cyclic Aminomethylphosphine Ligands for the Construction of Catalysts for Electrochemical Hydrogen Transformations. Chem. Eur. J. 2014, 20, 3169-3182. [CrossRef] [PubMed]

3. Bullock, R.M.; Helm, M.L. Molecular Electrocatalysts for Oxidation of Hydrogen Using Earth-Abundant Metals: Shoving Protons Around with Proton Relays. Acc. Chem. Res. 2015, 48, 2017-2026. [CrossRef] [PubMed]

4. Kadirov, M.K.; Karasik, A.A.; Nizameev, I.R.; Strelnik, I.D.; Kholin, K.V.; Kadirov, D.M.; Ismaev, T.I.; Budnikova, Y.G.; Sinyashin, O.G. Organometallic Polymer Electrolyte Membrane Fuel Cell Bis-Ligand Nickel(II) Complex of 1,5-Di-P-Tolyl-3,7-Dipyridine-1,5,3,7-Diazadiphosphacyclooctane Catalyst. Energy Technol. 2018, 6, 1088-1095. [CrossRef]

5. Prokopchuk, D.E.; Wiedner, E.S.; Walter, E.D.; Popescu, C.V.; Piro, N.A.; Kassel, W.S.; Bullock, R.M.; Mock, M.T. Catalytic $\mathrm{N}_{2}$ Reduction to Silylamines and Thermodynamics of $\mathrm{N}_{2}$ Binding at Square Planar Fe. J. Am. Chem. Soc. 2017, 139, 9291-9301. [CrossRef]

6. Burgess, S.A.; Grubel, K.; Appel, A.M.; Wiedner, E.S.; Linehan, J.C. Hydrogenation of $\mathrm{CO}_{2}$ at Room Temperature and Low Pressure with a Cobalt Tetraphosphine Catalyst. Inorg. Chem. 2017, 56, 8580-8589. [CrossRef]

7. Karasik, A.A.; Balueva, A.S.; Musina, E.I.; Sinyashin, O.G. Chelating cyclic aminomethylphosphines and their transition metal complexes as a promising basis of bioinspired mimetic catalysts. Mendeleev Commun. 2013, 23, 237-248. [CrossRef]

8. Shaw, W.J.; Helm, M.L.; DuBois, D.L. A modular, energy-based approach to the development of nickel containing molecular electrocatalysts for hydrogen production and oxidation. Biochim. Biophys. Acta. 2013, 1827, 1123-1139. [CrossRef]

9. Bullock, R.M.; Das, A.K.; Appel, A.M. Surface Immobilization of Molecular Electrocatalysts for Energy Conversion. Chem. Eur. J. 2017, 23, 7626-7641. [CrossRef]

10. Klug, C.M.; Cardenas, A.J.P.; Bullock, R.M.; O'Hagan, M.; Wiedner, E.S. Reversing the Tradeoff Between Rate and Overpotential in Molecular Electrocatalysts for H 2 Production. ACS Catal. 2018, 8, 3286-3296. [CrossRef]

11. Lense, S.; Dutta, A.; Roberts, J.A.S.; Shaw, W.J. A proton channel allows a hydrogen oxidation catalyst to operate at a moderate overpotential with water acting as a base. Chem. Commun. 2014, 50, 792-795. [CrossRef] [PubMed] 
12. Klug, C.M.; Dougherty, W.G.; Kassel, W.S.; Wiedner, E.S. Electrocatalytic Hydrogen Production by a Nickel Complex Containing a Tetradentate Phosphine Ligand. Organometallics 2019, 38, 1269-1279. [CrossRef]

13. Khrizanforova, V.V.; Musina, E.I.; Khrizanforov, M.N.; Gerasimova, T.P.; Katsyuba, S.A.; Spiridonova, Y.S.; Islamov, D.R.; Kataeva, O.N.; Karasik, A.A.; Sinyashin, O.G.; et al. Unexpected ligand effect on the catalytic reaction rate acceleration for hydrogen production using biomimetic nickel electrocatalysts with 1,5-diaza-3,7-diphosphacyclooctanes. J. Organomet. Chem. 2015, 789-790, 14-21. [CrossRef]

14. Mock, M.T.; Chen, S.; O'Hagan, M.; Rousseau, R.; Dougherty, W.G.; Kassel, W.S.; Bullock, R.M. Dinitrogen Reduction by a Chromium (0) Complex Supported by a16-Membered Phosphorus Macrocycle. J. Am. Chem. Soc. 2013, 135, 11493-11496. [CrossRef] [PubMed]

15. Strelnik, I.D.; Dayanova, I.R.; Poryvaev, T.M.; Gerasimova, T.P.; Litvinov, I.A.; Katsyuba, S.A.; Musina, E.I.; Karasik, A.A.; Sinyashin, O.G. Rearrangement of two 8-membered 1,5-diaza-3,7-diphosphacyclooctane rings into 16-membered $\mathrm{P}_{4} \mathrm{~N}_{4}$ ligand on the gold(I) template. Mendeleev Commun. 2020, 30, 40-42. [CrossRef]

16. Strelnik, I.D.; Gurzhiy, V.V.; Sizov, V.V.; Musina, E.I.; Karasik, A.A.; Tunik, S.P.; Grachova, E.V. A stimuli-responsive $\mathrm{Au}(\mathrm{I})$ complex based on an aminomethylphosphine template: Synthesis, crystalline phases and luminescence properties. Cryst. Eng. Comm. 2016, 18, 7629-7635. [CrossRef]

17. Elistratova, J.; Strelnik, I.; Brylev, K.; Shestopalov, M.; Gerasimova, T.; Babaev, V.; Kholin, K.; Dobrynin, A.; Musina, E.; Katsyuba, S.; et al. Novel water soluble cationic Au(I) complexes with cyclic PNNP ligand as building blocks for heterometallic supramolecular assemblies with anionic hexarhenium cluster units. J. Lumin. 2018, 196, 485-491. [CrossRef]

18. Prokopchuk, D.E.; Chambers, G.M.; Walter, E.D.; Mock, M.T.; Bullock, R.M. $\mathrm{H}_{2}$ Binding, Splitting, and Net Hydrogen Atom Transfer at a Paramagnetic Iron Complex. J. Am. Chem. Soc. 2019, 141, 1871-1876. [CrossRef]

19. Liu, T.; DuBois, D.L.; Bullock, R.M. An iron complex with pendent amines as a molecular electrocatalyst for oxidation of hydrogen. Nat. Chem. 2013, 5, 228-233. [CrossRef]

20. Liu, T.; Liao, Q.; O’Hagan, M.; Hulley, E.B.; DuBois, D.L.; Bullock, R.M. Iron Complexes Bearing Diphosphine Ligands with Positioned Pendant Amines as Electrocatalysts for the Oxidation of $\mathrm{H}_{2}$. Organometallics 2015, 34, 2747-2764. [CrossRef]

21. Jacobsen, G.M.; Shoemaker, R.K.; McNevin, M.J.; Rakowski DuBois, M.; DuBois, D.L. Syntheses and Structural Characterizations of Iron (II) Complexes Containing Cyclic Diphosphine Ligands with Positioned Pendant Nitrogen Bases. Organometallics 2007, 26, 5003-5009. [CrossRef]

22. Liu, T.; Chen, S.; O’Hagan, M.J.; Rakowski DuBois, M.; Bullock, R.M.; DuBois, D.L. Synthesis, Characterization, and Reactivity of Fe Complexes Containing Cyclic Diazadiphosphine Ligands: The Role of the Pendant Base in Heterolytic Cleavage of $\mathrm{H}_{2}$. J. Am. Chem. Soc. 2012, 134, 6257-6272. [CrossRef] [PubMed]

23. Liao, Q.; Liu, T.; Johnson, S.I.; Klug, C.M.; Wiedner, E.S.; Bullock, R.M.; DuBois, D.L. Evaluation of attractive interactions in the second coordination sphere of iron complexes containing pendant amines. Dalton Trans. 2019, 48, 4867-4878. [CrossRef] [PubMed]

24. Orthaber, A.; Karnahl, M.; Tschierlei, S.; Streich, D.; Stein, M.; Ott, S. Coordination and conformational isomers in mononuclear iron complexes with pertinence to the [FeFe] hydrogenase active site. Dalton Trans. 2014, 43, 4537-4549. [CrossRef] [PubMed]

25. Liu, T.; Wang, X.; Hoffmann, C.; DuBois, D.L.; Bullock, R.M. Heterolytic Cleavage of Hydrogen by an Iron Hydrogenase Model: An Fe-H...H-N Dihydrogen Bond Characterized by Neutron Diffraction. Angew. Chem. Int. Ed. 2014, 53, 5300-5304. [CrossRef]

26. Kumar, N.; Darmon, J.M.; Weiss, C.J.; Helm, M.L.; Raugei, S.; Bullock, R.M. Outer Coordination Sphere Proton Relay Base and Proximity Effects on Hydrogen Oxidation with Iron Electrocatalysts. Organometallics 2019, 38, 1391-1396. [CrossRef]

27. Karasik, A.A.; Naumov, R.N.; Balueva, A.S.; Spiridonova, Y.S.; Golodkov, O.N.; Novikova, H.V.; Belov, G.P.; Katsyuba, S.A.; Vandyukova, E.E.; Lönnecke, P.; et al. Synthesis, Structure, and Transition Metal Complexes of Amphiphilic 1,5-Diaza-3,7-diphosphacyclooctanes. Heteroat. Chem. 2006, 17, 499-513. [CrossRef]

28. Ignatieva, S.N.; Balueva, A.S.; Karasik, A.A.; Latypov, S.K.; Nikonova, A.G.; Naumova, O.E.; Lönnecke, P.; Hey-Hawkins, E.; Sinyashin, O.G. First Representative of Optically Active P-L-Menthyl-Substituted (Aminomethyl)phosphine and Its Borane and Metal Complexes. Inorg. Chem. 2010, 49, 5407-5412. [CrossRef] 
29. Latypov, S.K.; Strelnik, A.G.; Ignatieva, S.N.; Hey-Hawkins, E.; Balueva, A.S.; Karasik, A.A.; Sinyashin, O.G. Structure and Dynamics of P, N-Containing Heterocycles and Their Metal Complexes in Solution. J. Phys. Chem. A 2012, 116, 3182-3193. [CrossRef]

30. Burrows, A.D.; Dodds, D.; Kirk, A.S.; Lowe, J.P.; Mahon, M.F.; Warren, J.E.; Whittlesey, M.K. Substitution and derivatization reactions of a water soluble iron (II) complex containing a self-assembled tetradentate phosphine ligand. Dalton Trans. 2007, 570-580. [CrossRef]

31. Burrows, A.D.; Harrington, R.W.; Kirk, A.S.; Mahon, M.F.; Marken, F.; Warren, J.E.; Whittlesey, M.K. Synthesis, Characterization, and Electrochemistry of a Series of Iron(II) Complexes Containing Self-Assembled 1,5-Diaza-3,7-diphosphabicyclo[3.3.1]nonane Ligands. Inorg. Chem. 2009, 48, 9924-9935. [CrossRef] [PubMed]

32. Landau, S.E.; Morris, R.H.; Lough, A.J. Acidic Dicationic Iron (II) Dihydrogen Complexes and Compounds Related by $\mathrm{H}_{2}$ Substitution. Inorg. Chem. 1999, 38, 6060-6068. [CrossRef] [PubMed]

33. Halfen, J.A.; Moore, H.L.; Fox, D.C. Synthetic Models of the Reduced Active Site of Superoxide Reductase. Inorg. Chem. 2002, 41, 3935-3943. [CrossRef] [PubMed]

34. Vela, J.; Smith, J.M.; Yu, Y.; Ketterer, N.A.; Flaschenriem, C.J.; Lachicotte, R.J.; Holland, P.L. Synthesis and Reactivity of Low-Coordinate Iron (II) Fluoride Complexes and Their Use in the Catalytic Hydrodefluorination of Fluorocarbons. J. Am. Chem. Soc. 2005, 127, 7857-7870. [CrossRef] [PubMed]

35. Quesada, M.; de la Peña-O'Shea, V.A.; Aromí, G.; Geremia, S.; Massera, C.; Roubeau, O.; Gamez, P.; Reedijk, J. A Molecule-Based Nanoporous Material Showing Tuneable Spin-Crossover Behavior near Room Temperature. Adv. Mater. 2007, 19, 1397-1402. [CrossRef]

36. Zhang, Q.; Xiang, L.; Deng, L. Dinuclear Iron-Imido Complexes with N-Heterocyclic Carbene Ligation: Synthesis, Structure, and Redox Reactivity. Organometallics 2012, 31, 4537-4543. [CrossRef]

37. Ke, C.-H.; Chen, C.-H.; Tsai, M.-L.; Wang, H.-C.; Tsai, F.-T.; Chiang, Y.-W.; Shih, W.-C.; Bohle, D.S.; Liaw, W.-F. $\left\{\mathrm{Fe}(\mathrm{NO})_{2}\right\}^{9}$ Dinitrosyl Iron Complex Acting as a Vehicle for the NO Radical. J. Am. Chem. Soc. 2017, 139, 67-70. [CrossRef]

38. Hemming, E.B.; Chan, B.; Turner, P.; Corcilius, L.; Price, J.R.; Gardiner, M.G.; Masters, A.F.; Maschmeyer, T. $\left[\mathrm{Fe}\left(\mathrm{C}_{5} \mathrm{Ar}_{5}\right)(\mathrm{CO})_{2} \mathrm{Br}\right]$ complexes as hydrogenase mimics for the catalytic hydrogen evolution reaction. Appl. Catal. B Environ. 2018, 223, 234-241. [CrossRef]

39. Narwane, M.; Chang, Y.-L.; Ching, W.-M.; Tsai, M.-L.; Hsu, S.C.N. Investigation on the coordination behaviors of tris(2-pyridyl) pyrazolyl borates iron (II) complexes. Inorg. Chim. Acta. 2019, 495, 118966. [CrossRef]

40. Horn, E.; Snow, M.R.; Tiekink, E.R.T. A Polymeric Silver Lutidine Tetrafluoroborate Compound, $\left[\mathrm{Ag}(\mathrm{lut})_{2}\left(\mu_{4}-\mathrm{BF}_{4}\right)\right] \mathrm{N}$, with Weak $\mu_{4}$-Tetrafluoroborate Coordination to Silver. Aust. J. Chem. 1987, 40, 761-765. [CrossRef]

41. Blake, A.J.; Brooks, N.R.; Champness, N.R.; Cunningham, J.W.; Hubberstey, P.; Schröder, M. Thioether ligands as molecular rods in silver(I) coordination networks: 1,4-dithiane as an analogue of pyrazine. CrystEngComm 2000, 6, 41-45. [CrossRef]

42. Fenton, H.; Tidmarsh, I.S.; Ward, M.D. Hierarchical self-assembly of heteronuclear co-ordination networks. Dalton Trans. 2010, 39, 3805-3815. [CrossRef] [PubMed]

43. Kilduff, B.; Pogozhev, D.; Baudron, S.A.; Hosseini, M.W. Heterometallic Architectures Based on the Combination of Heteroleptic Copper and Cobalt Complexes with Silver Salts. Inorg. Chem. 2010, 49, 11231-11239. [CrossRef] [PubMed]

44. Poorters, L.; Armspach, D.; Matt, D.; Toupet, L.; Jones, P.G. A Metallocavitand Functioning as a Container for Anions: Formation of Noncovalent Linear Assemblies Mediated by a Cyclodextrin-Entrapped $\mathrm{NO}_{3}$ Ion. Angew. Chem. Int. Ed. 2007, 46, 2663-2665. [CrossRef] [PubMed]

45. Cimadevilla, F.; García, E.M.; García-Vivó, D.; Ruiz, M.A.; Rueda, M.T.; Halut, S. Protonation reactions of the oxo complex cis-[ $\left[\mathrm{Mo}_{2}\left(\mathrm{~h}^{5}-\mathrm{C}_{5} \mathrm{H}_{5}\right)_{2}(\mathrm{O})(\mu-\mathrm{PPh} 2) 2(\mathrm{CO})\right]$. Hydroxo and tetrafluoroborate derivatives. J. Organomet. Chem. 2012, 699, 67-74. [CrossRef]

46. Musina, E.I.; Karasik, A.A.; Balueva, A.S.; Strelnik, I.D.; Fesenko, T.I.; Dobrynin, A.B.; Gerasimova, T.P.; Katsyuba, S.A.; Kataeva, O.N.; Lönnecke, P.; et al. Synthesis and Stereoselective Interconversion of Chiral 1-Aza-3,6-diphosphacycloheptanes. Eur. J. Inorg. Chem. 2012, 2012, 1857-1866. [CrossRef]

47. Kilgore, U.J.; Roberts, J.A.S.; Pool, D.H.; Appel, A.M.; Stewart, M.P.; Rakowski DuBois, M.; Dougherty, W.G.; Kassel, W.S.; Bullock, R.M.; DuBois, D.L. $\left[\mathrm{Ni}\left(\mathrm{P}^{\mathrm{Ph}}{ }_{2} \mathrm{~N}^{\mathrm{C} 6 \mathrm{H} 4 \mathrm{X}}{ }_{2}\right)_{2}\right]^{2+}$ Complexes as Electrocatalysts for $\mathrm{H}_{2}$ Production: Effect of Substituents, Acids, and Water on Catalytic Rates. J. Am. Chem. Soc. 2011, 133, 5861-5872. [CrossRef] 
48. Kilgore, U.J.; Stewart, M.P.; Helm, M.L.; Dougherty, W.G.; Kassel, W.S.; Rakowski DuBois, M.; DuBois, D.L.; Bullock, R.M. Studies of a Series of $\left[\mathrm{Ni}\left(\mathrm{P}^{\mathrm{R}}{ }_{2} \mathrm{~N}^{\mathrm{Ph}}{ }_{2}\right)_{2}(\mathrm{CH} 3 \mathrm{CN})\right]^{2+}$ Complexes as Electrocatalysts for $\mathrm{H}_{2}$ Production: Substituent Variation at the Phosphorus Atom of the $\mathrm{P}_{2} \mathrm{~N}_{2}$ Ligand. Inorg. Chem. 2011, 50, 10908-10918. [CrossRef]

49. Sheldrick, G.M. SHELXT-Integrated space-group and crystal-structure determination. Acta Crystallogr. Sect. A Found. Adv. 2015, 71, 3-8. [CrossRef]

50. Sheldrick, G.M. Crystal structure refinement with SHELXL Acta Crystallogr. Sect. C Struct. Chem. 2015, 71,3-8. [CrossRef]

51. Farrugia, L.J.J. WinGX and ORTEP for Windows: An update. Appl. Crystallogr. 2012, 45, 849-854. [CrossRef]

52. Flack, H.D.; Bernardinelli, G. Reporting and evaluating absolute-structure and absolute-configuration determinations. J. Appl. Crystallogr. 2000, 33, 1143-1148. [CrossRef]

53. Spek, A.L. Structure validation in chemical crystallography. Acta Crystallogr. Sect. D Struct. Biol. 2009, 65, 148-155. [CrossRef] [PubMed]

Sample Availability: Samples of the compounds 6-13 are available from the authors.

(C) 2020 by the authors. Licensee MDPI, Basel, Switzerland. This article is an open access article distributed under the terms and conditions of the Creative Commons Attribution (CC BY) license (http://creativecommons.org/licenses/by/4.0/). 